Article

\title{
Solvent-Free Biginelli Reactions Catalyzed by Hierarchical Zeolite Utilizing a Ball Mill Technique: A Green Sustainable Process
}

\author{
Ameen Shahid ${ }^{1}$, Nesreen S. Ahmed ${ }^{2,3}$, Tamer S. Saleh ${ }^{4,5, *}$, Shaeel Ahmed Al-Thabaiti ${ }^{2}$, \\ Sulaiman N. Basahel ${ }^{2}$, Wilhelm Schwieger ${ }^{1}$ and Mohamed Mokhtar ${ }^{2,6, *}$ \\ 1 Institute of Chemical Reaction Technology, Friedrich-Alexander-Universität Erlangen-Nürnberg, \\ 91058 Erlangen, Germany; ameen.shahid@cbi.uni-erlangen.de (A.S.); \\ Wilhelm.Schwieger@crt.cbi.uni-erlangen.de (W.S.) \\ 2 Department of Chemistry, Faculty of Science, King Abdulaziz University, P.O. Box 80203, \\ Jeddah 21589, Saudi Arabia; nesreen69eg@yahoo.com (N.S.A.); sthabiti@hotmail.com (S.A.A.-T.); \\ sbasahel@hotmail.com (S.N.B.) \\ 3 Medicinal Chemistry Department, National Research Centre, El Buhouth St., Dokki, Cairo 12622, Egypt \\ 4 Department of Chemistry, Faculty of Science, University of Jeddah, P.O. Box 80329, \\ Jeddah 21589, Saudi Arabia \\ 5 Green Chemistry Department, National Research Centre, Dokki, Cairo 12622, Egypt \\ 6 Surface Chemistry and Catalysis Lab, Physical Chemistry Department, National Research Centre, \\ El Buhouth St., Dokki, Cairo 12622, Egypt \\ * Correspondence: tssayed@uj.edu.sa (T.S.S.); mmoustafa@kau.edu.sa (M.M.); \\ Tel.: +966565176223 (T.S.S.); +966500558045 (M.M.); Fax: +966-26952292 (T.S.S.); +966-26952292 (M.M.)
}

Academic Editor: Giancarlo Cravotto

Received: 3 February 2017; Accepted: 6 March 2017; Published: 13 March 2017

\begin{abstract}
A sustainable, green one-pot process for the synthesis of dihydropyrimidinones (DHPMs) derivatives by a three-component reaction of $\beta$-ketoester derivatives, aldehyde and urea or thiourea over the alkali-treated H-ZSM-5 zeolite under ball-milling was developed. Isolation of the product with ethyl acetate shadowed by vanishing of solvent was applied. The hierachical zeolite catalyst (MFI27_6) showed high yield (86\%-96\%) of DHPMs in a very short time (10-30 min). The recyclability of the catalyst for the subsequent reactions was examined in four subsequent runs. The catalyst was shown to be robust without a detectable reduction in catalytic activity, and high yields of products showed the efficient protocol of the Biginelli reactions.
\end{abstract}

Keywords: hierarchical; MFI27; Biginelli; dihydropyrimidinones; ball mill

\section{Introduction}

The improvement of synthetic processes by saving resources, energy and avoiding wastes and pollution during the preparation of a common product (or even a better product) is the main goal of chemists who believe in chemical sustainability. Sustainability can be improved by various approaches, some of which are: (i) non-classical energy routes like ultrasound, microwave or mechanochemical process; (ii) catalysis, which is a good alternative to stoichiometric processes; (iii) solvent-free reactions; (iv) solid-phase syntheses. All of these tools may be helpful in numerous cases. However, the essential examination actions will diminish with sustainability since liquid state reactions are seldom measurable.

The production of useful compounds in an economical, energy-saving and environmentally acceptable way requires us to follow catalysis pathway. In addition, catalysis is an important green chemistry principal. Ideally, our goal is to synthesize the compounds with a $100 \%$ yield 
and $100 \%$ selectivity with minimal waste amounts. This method essential to be cost-effective, safe, resource-efficient, energy-efficient and ecologically benign. In this respect, the atom economy [1] and the E-factor [2] must be taken into account.

On the other hand, the modern drug discovery processes require the use of a multicomponent as a key source of molecular diversity. Moreover, the one-pot synthesis provides minimal by-products, low cost, shorter time and lower energy in comparison to the classical stepwise synthetic route. The Biginelli reaction is considered to be one of the most studied multicomponent reactions. The reaction products of the reaction are dihydropyrimidinones (DHPMs), which are energetic therapeutic synthons that show a varied range of biological actions such as antiseptic, anti-inflammatory, antiviral, anti-tumor [3-5]. A huge number of dihydropyrimidinones derivatives have biological value, e.g., antagonists, antihypertensive agents, significant calcium channel blockers, and neuropeptide antagonists [6-11]. The research into structural modification of DHPMs 1 has led to the discovery of pharmacologically active compounds, as represented in the DHPMs scaffold (Figure 1).<smiles>[Y]O[Os]</smiles>

O. Molecular diveristy

Figure 1. The design of a bioactive dihydropyrimidinones (DHPMs) scaffold has many variables and parts.

Additionally, the diaryl sulfone purpose remained an effective antimicrobial agent [12]. Dapsone [13] and Promine [14] (Figure 2) are specimens of some famous drugs, that comprise diaryl sulfone function, and are widely available in the market. Notably, the blend of a diaryl sulfone ring with several forms of heterocyclic equivalents exhibited significant biological actions [15-19]. Therefore, the insertion of a diaryl sulfone moiety to the DHPMs could provide novel derivatives of expected biological and pharmacological activities.

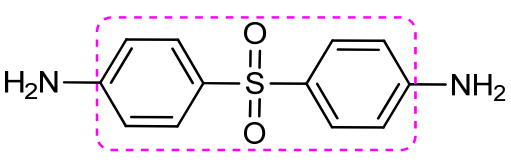

Dapsone

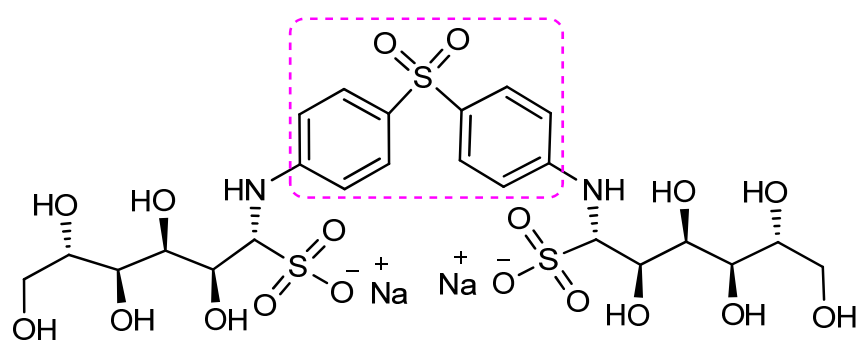

Promin

Figure 2. Selected drug molecules that contain diaryl sulfone moieties.

The commonly-used homogeneous catalysts for Biginelli reactions, such as $\mathrm{BF}_{3} \cdot \mathrm{Et}_{2} \mathrm{O}, \mathrm{InCl}_{3}$, $\mathrm{LaCl}_{3}, \mathrm{Sr}\left(\mathrm{NO}_{3}\right)_{2}$, and ceric ammonium nitrate have several drawbacks, such as separation difficulties, recovery processes, pre-used catalyst's disposal, toxicity and corrosion [20-24]. The utilization of solid heteropolyacids (HPAs) as alternative heterogeneous catalysts for conventionally homogenous analogs, such as hydrofluoric and sulfuric acids, has been well known for many years [25]. However, HPAs, which are utilized as an acid catalyst for the transformation reactions [26], suffer from their 
recovery and reuse in presence of water and organic solvents $[27,28]$. To overcome these drawbacks, heterogenization of HPAs into different host supports like silica [29] and activated carbon [30] were reported. Nonetheless, these braced catalytic reagents lean towards controlled POM loading, display some leaching and are liable to accumulation [31]. On the other hand, dihydropyrimidinones were synthesized via Biginelli cyclocondensation utilizing KSF montmorillonite [32] and zeolite [33] catalysts. A moderate yield using environmentally unfavorable solvent with a long reaction time was attained. Tajbakhsh et al. [34] used natural zeolite Heulandite, which resulted in a good dihydropyrimidinones derivatives yield $(75 \%)$ in $4-5 \mathrm{~h}$ at $100{ }^{\circ} \mathrm{C}$. Table 1 summarizes the utilization of zeolite catalysts for Biginelli reaction in the last two decades.

Table 1. Utilization of zeolite catalysts for Biginelli reaction in last two decades.

General Biginelli Reaction:

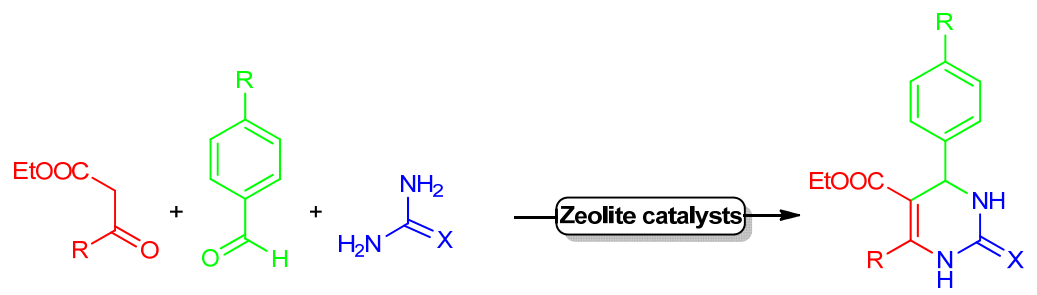

\begin{tabular}{ccccccc}
\hline Entry & Type of Zeolite Used & Method & Time (h) & Yield & Reference & Temperature $\left({ }^{\circ} \mathbf{C}\right)$ \\
\hline 1 & Commercial HZSM-5 & Reflux in toluene & 24 & $21 \%$ & {$[33]^{\mathrm{a}}$} & 100 \\
2 & Commercial HY & Reflux in toluene & 24 & $80 \%$ & {$[33]^{\mathrm{a}}$} & 100 \\
3 & MCM-41 & Reflux in toluene & 24 & $38 \%$ & {$[33]^{\mathrm{a}}$} & 100 \\
4 & Natural zeolite Heulandite & Reflux in acetic acid & 5 & $75 \%$ & {$[34]^{\mathrm{a}}$} & 100 \\
5 & Metal/Y zeolite & Reflux in ethanol & 12 & $20 \%-38 \%$ b & {$[35]^{\mathrm{a}}$} & 70 \\
\hline
\end{tabular}

${ }^{a}$ The results obtained for the-the reaction of ethyl acetoacetate, benzaldehyde, and urea; ${ }^{b}$ Depending on the type of metal used.

However, the drawback of the published work using zeolite catalysts for the Biginelli reaction is the long working time under hazards conditions and the moderate product yield (Table 1). It was reported that the desilication and subsequent dealumination of HZSM5 shorten the diffusion path length and enhance the transport rate of all aromatic molecules [36-38], leading to enhanced activity and selectivity compared to the parent material [35,39].

Regarding the efficient green methods applied to distributing energy for chemical processes, it was found that ball milling technique relative to other methods can be efficiently applied in the field of sustainable synthesis. There is lack of knowledge about organic chemists in ball mills chemistry. The interest in this technique has intensified in the last 10 years, resulting in frequent, acceptable synthetic methods that covering the whole scope of organic synthesis [40,41]. More recently, a solvent-free ball milling Biginelli reaction utilizing subcomponent synthesis was reported [42]. The main drawback of this reported method is the two-step synthesis procedure, a tedious working procedure, the requirement of column chromatography for purification of the products, and high cost of the self-catalyst's precursor.

In the present work, we present a strategy to synthesize hierarchical ZSM- 5 by post treatments of commercial H-ZSM-5. We aim to improve its catalytic performance towards Biginelli reaction and introduce novel DHPMs derivatives that contain diarylsulfone moiety under solvent-free conditions utilizing a ball mill technique in a one-pot fashion. The presented catalyst is robust, easily re-coverable and can be re-used for four periods when noteworthy damage of its activity is avoided. Hence, a small reaction period, simplistic retrieval and reprocessing of the catalyst and solvent-free conditions mean that our process is more beneficial than other processes. 


\section{Results and Discussions}

\subsection{Powder X-ray Diffraction (PXRD)}

X-ray diffraction of as-received ZSM-5 and alkali-treated zeolite samples are presented in Figure 3. All the diffraction patterns are assigned to MFI structure, where the diffraction patterns at around $23^{\circ}$, $23.07^{\circ}$ and $23.25^{\circ}$, respectively, were detected. The intensity and lattice parameters of MFI structure were unchanged for all the investigated samples. However, MFI27_6 showed slightly lower peak intensities and less line broadening than the other treated zeolites. This slight change in diffraction patterns after a long period of alkali-treatment for is probably due to smaller crystalline domains and pore widening due to the extraction of silicon [43].

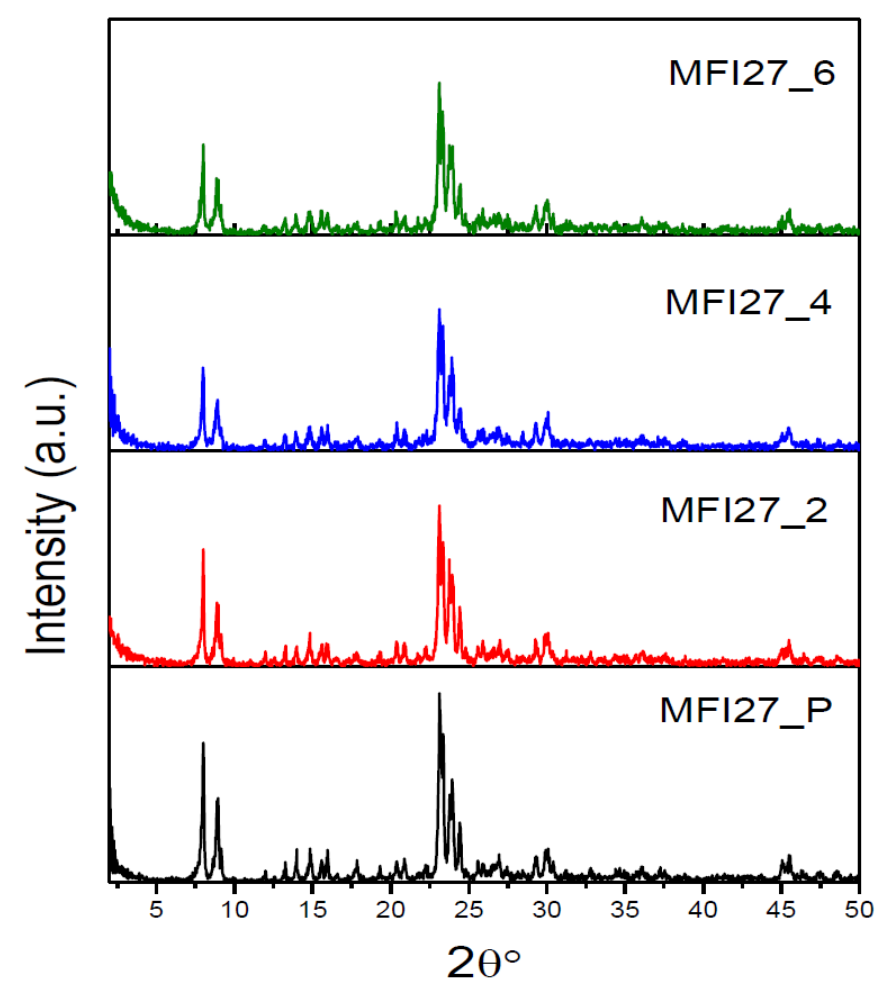

Figure 3. X-ray diffraction patterns for parent and alkali-treated ZSM-5 catalysts.

\section{2. $\mathrm{N}_{2}$ Physisorption}

When treated with alkali, the as-received ZSM-5 usually resulted in a possible selective extraction of Si [43]. Table 2 shows that the Si/Al ratio calculated for MFI samples decreases as the time of alkali-treatment increases while no significant structural changes take place, as shown from X-ray diffraction patterns. A pronounced difference in the textural properties between as-received MFI27_P and alkali-treated samples was recorded by $\mathrm{N}_{2}$-adsorption measurements. Figure 4 shows the $\mathrm{N}_{2}$ adsorption/desorption isotherms on as-received MFI27_P and other treated zeolite samples. MFI27_P shows a type I, while the alkali-treated samples show a combined type I and IV isotherm. The horizontal shape of the hysteresis loop in isotherms of alkali-treated samples indicates inkbottle-type mesopores [44]. 


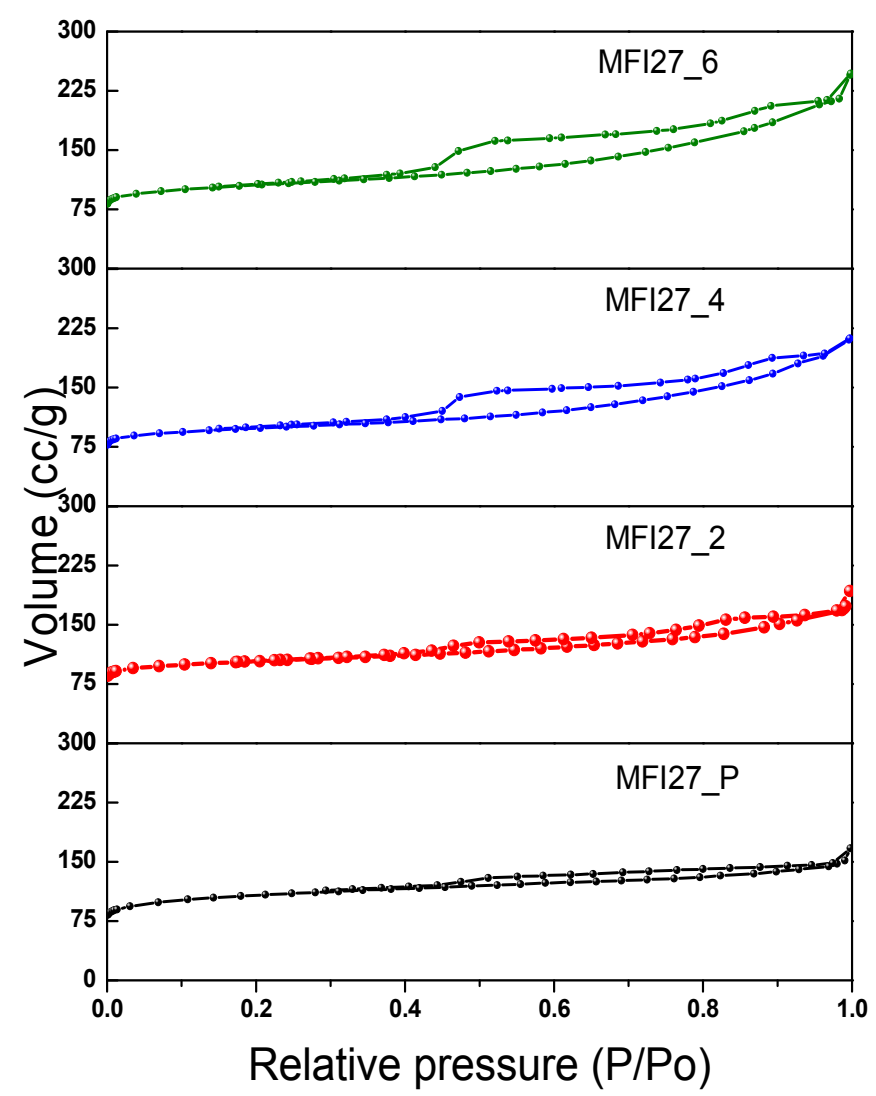

Figure 4. $\mathrm{N}_{2}$ adsorption/desorption isotherms of as-received ZSM-5 and alkali-treated zeolite samples.

Figure 5 illustrates the pore size distributions using the Non-Local Density Functional Theory (NLDFT) method for the adsorption branch of isotherms. There is a right-shift in the pore size towards mesoporous range with the extended time of treatment with alkali. The diameter of the mesopores slightly increased and a sharp distribution around $7 \mathrm{~nm}$ was observed after $6 \mathrm{~h}$ of alkali-treatment (MFI27_6).

Table 2 shows the BET surface area $\left(S_{\mathrm{BET}}\right)$, micropore surface area $\left(S_{\text {micro }}\right)$, mesopore surface area $\left(S_{\text {meso }}\right)$, total pore volume $\left(V_{\text {total }}\right)$ micropore volume $\left(V_{\text {micro }}\right)$, and mesopore volume $\left(V_{\text {meso }}\right)$ of all the investigated samples. The values of $V_{\text {micro }}$ and $S_{\text {micro }}$ were decreased from their original values, while those of $V_{\text {meso }}$ and $S_{\text {meso }}$ increased by alkali-treatment for MFI27_P sample. The increase in the pore volume with diameters of approximately $4-7 \mathrm{~nm}$ for the desilicated samples confirmed the generation of mesopores by desilication. Deposition of the dissolved amorphous $\mathrm{SiO}_{2}$ overlayer decreased the micropore volume and BET-surface area due to blocking of some pores $[45,46]$. The hierarchy factor $(\mathrm{HF})$ increases after the alkali treatment of the parent sample which indicates that the external surface area was enhanced and there was a significant reduction in the micropore volume. However, all alkali-treated samples (MFI27_2, MFI27_4 and MFI27_6) have approximately the same HF. 


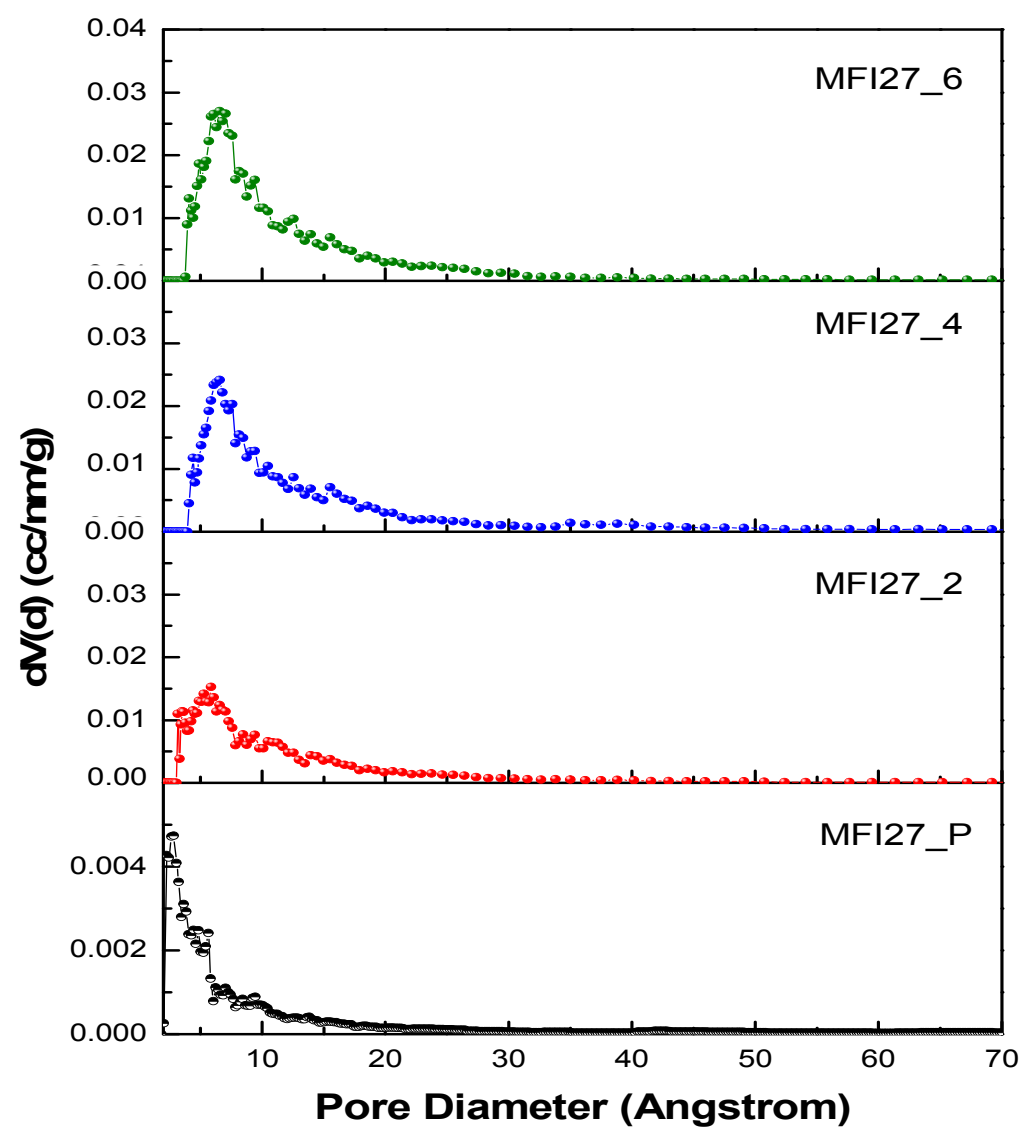

Figure 5. Pore size distribution of as-received ZSM-5 and alkali-treated zeolite samples.

Table 2. Si / Al ratio, physicochemical properties of the parent and post modified zeolites.

\begin{tabular}{|c|c|c|c|c|c|c|c|c|}
\hline Samples & Si/Al & $\begin{array}{l}S_{\mathrm{BET}}{ }^{\mathrm{a}} \\
\left(\mathrm{m}^{2} / \mathrm{g}\right)\end{array}$ & $\begin{array}{l}S_{\text {micro }} \\
\left(\mathrm{m}^{2} / \mathrm{g}\right)\end{array}$ & $\begin{array}{l}S_{\text {meso }} \\
\left(\mathrm{m}^{2} / \mathrm{g}\right)\end{array}$ & $\begin{array}{l}V_{\text {Total }} \mathrm{b} \\
\left(\mathrm{cm}^{3} / \mathrm{g}\right)\end{array}$ & $\begin{array}{l}V_{\text {micro }}{ }^{c} \\
\left(\mathrm{~cm}^{3} / \mathrm{g}\right)\end{array}$ & $\begin{array}{l}V_{\text {meso }} \mathrm{d} \\
\left(\mathrm{cm}^{3} / \mathrm{g}\right)\end{array}$ & $\begin{array}{l}\text { Hierarchy } \\
\text { Factor } \mathrm{e}\end{array}$ \\
\hline MFI27_P & 13 & 399 & 360 & 39 & 0.25 & 0.16 & 0.09 & 0.063 \\
\hline MFI27_2 & 10.9 & 356 & 268 & 88 & 0.29 & 0.12 & 0.17 & 0.102 \\
\hline MFI27_4 & 9.8 & 334 & 196 & 138 & 0.32 & 0.08 & 0.24 & 0.103 \\
\hline MFI27_6 & 8.6 & 363 & 200 & 163 & 0.38 & 0.08 & 0.30 & 0.095 \\
\hline
\end{tabular}

${ }^{a}$ BET surface area; ${ }^{\mathrm{b}}$ Total pore volume at $P / P_{\mathrm{o}}=0.997 ;{ }^{\mathrm{c}}$ Micropore volume from $t$-plot; ${ }^{\mathrm{d}} V_{\text {meso }}=V_{\text {Total }}-V_{\text {micro; }}$;

e Hierarchy factor $=\left(V_{\text {micro }} / V_{\text {total }}\right) \times\left(S_{\text {meso }} / S_{\text {BET }}\right)$.

\subsection{Evaluation of the Acid Sites}

The change in acidic properties of H-ZSM- 5 as a result of treatment of as-received ZSM- 5 with alkali was investigated. No detectable change in acidity was recorded after treatment. Figure 6 shows the $\mathrm{NH}_{3}$-TPD profile for all the investigated samples. A broadening in the peak and lowering of intensities was recorded with the prolonged alkali-treatment. The calculated amounts of acid sites from the desorption at higher temperature, were $0.822 \mathrm{mmol} \cdot \mathrm{g}^{-1}$ for as-received ZSM-5, 0.667, 0.732, and $0.559 \mathrm{mmol} \cdot \mathrm{g}^{-1}$ for MFI27_2, MFI27_4, MFI27_6, respectively. Typical results of FTIR spectra for pyridine adsorption are illustrated in Figure 7. The band at $1520 \mathrm{~cm}^{-1}$ assigned to Brønsted acid sites did not change. On the other hand, the relative intensity of Lewis acid sites band at $1460 \mathrm{~cm}^{-1}$ slightly increased by alkali-treatment. Similar results were reported by Ogura et al. [36], where little dealumination of the zeolite sample occurred due to alkali-treatment. 


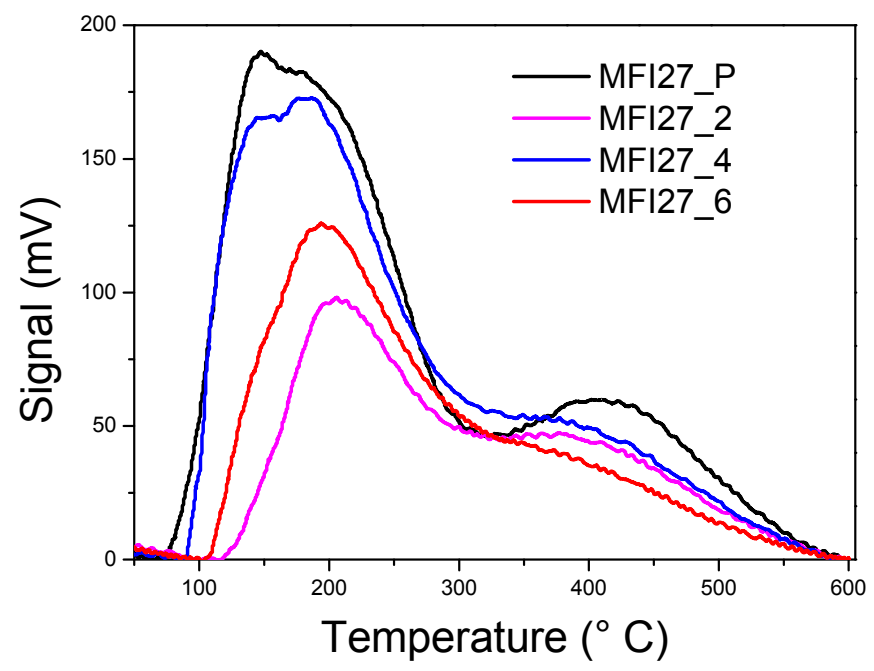

Figure 6. Ammonia temperature programmed desorption ( $\left.\mathrm{NH}_{3}-\mathrm{TPD}\right)$ profile of as-received ZSM-5 and alkali-treated zeolite samples.

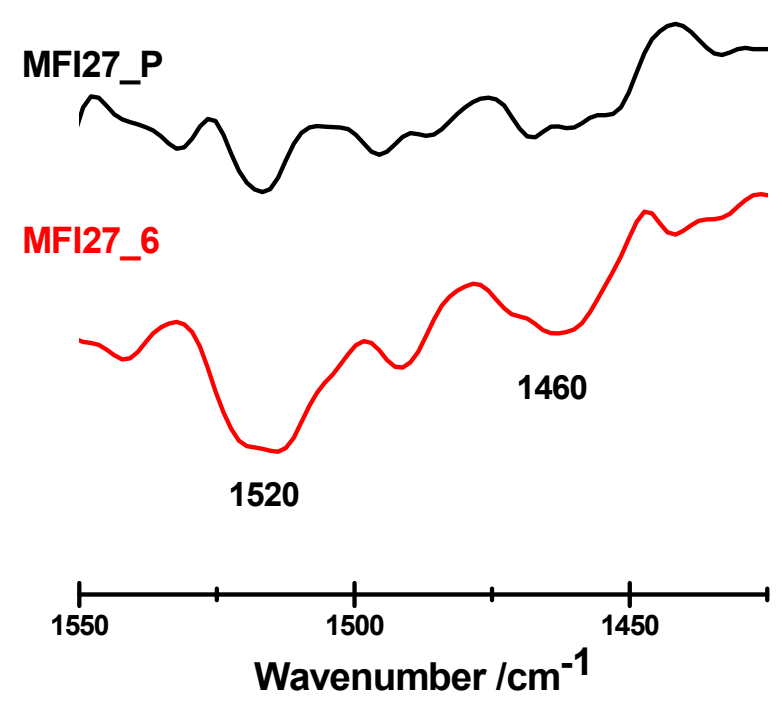

Figure 7. FTIR spectra of as-received MFI27_P and MFI27_6 zeolite samples.

\subsection{DHPM Synthesis}

The methodology has been very well studied by many other research groups $[47,48]$. However, to date none of those groups have studied Biginelli reaction by hierarchical zeolite. It is important to develop new methodologies in this area. The catalytic activity of the prepared zeolite catalysts was evaluated in the synthesis of DHPMs via the Biginelli reaction, where multicomponent reaction between ethyl acetoacetate 1a, benzaldehyde derivative 2a, and urea 3a (Scheme 1) was chosen. A ball-mill, solvent-free technique was applied and optimization of the reaction circumstances for this particular reaction was studied. Table 3 represents the data obtained from the catalyzed reactions. It is found that MFI27_6 catalyst showed the highest product \% yield (91\%) in the shortest time (20 min) utilizing $0.25 \mathrm{~g}$ of catalyst and $30 \mathrm{~Hz}$ ball-mill frequency. To optimize the effect of the catalyst's weight, different amounts of MFI_6 catalyst were used under the same reaction conditions, where $0.35 \mathrm{~g}$ of catalyst afforded products in excellent yields of $96 \%$ in $10 \mathrm{~min}$. In order to study the influence of the frequency of the ball mill on this catalyzed reaction, three reactions were performed with 15,25 and $30 \mathrm{~Hz}$ of the best catalyst loading (entries 5, 6 and 7). 
<smiles>CCOC(=O)CC(C)=O</smiles>

Scheme 1. Optimization of the reaction conditions for the three component reaction.

The best frequency for this reaction protocol proved to be $30 \mathrm{~Hz}$ (entry 5), in which the desired product was isolated in $96 \%$ yield.

The isolated product 4a gave satisfactory elemental analysis and the obtained spectroscopic data (IR, ${ }^{1} \mathrm{H}$ NMR, ${ }^{13} \mathrm{C}$ NMR, MS) was consistent with their assigned structure. The IR spectrum of the product showed the presence of an NH absorption band at $3218 \mathrm{~cm}^{-1}$, two carbonyl absorption bands at $1735,1680 \mathrm{~cm}^{-1}$ and two characteristic symmetrical and asymmetrical absorption band of sulfone group at 1310 and $1145 \mathrm{~cm}^{-1}$. The mass spectra of the insulated product $4 \mathbf{a}$, exhibited a peak matching the molecular ion at $m / z 400$. Its ${ }^{1} \mathrm{H}$ NMR spectrum revealed a singlet signal at $\delta$ a triplet signal at $\delta$ $1.16\left(\mathrm{CH}_{3}\right.$ ester, $\left.J=6.8 \mathrm{~Hz}\right), 2.35\left(\mathrm{CH}_{3}\right)$, a quartet signal at $\delta 4.07\left(\mathrm{CH}_{2}\right.$ ester, $\left.J=6.8 \mathrm{~Hz}\right)$, a doublet signal at $\delta 5.41(\mathrm{CH}-4)$ and two $\mathrm{D}_{2} \mathrm{O}$ exchangeable signals at $\delta 5.53,7.56$ due to two $\mathrm{NH}$ protons, respectively, in addition to aromatic protons as a multiplet at $\delta 6.90-7.33$.

Table 3. Optimization the reaction conditions for the Biginelli reaction.

\begin{tabular}{cccccc}
\hline Entry & Catalyst & Catalyst Weight (g) & Time (min) & Yield (\%) & Ball-Mill Frequency (Hz) \\
\hline 1 & MFI27_P & 0.25 & 60 & 21 & 30 \\
2 & MFI27_2 & 0.25 & 40 & 83 & 30 \\
3 & MFI27_4 & 0.25 & 35 & 86 & 30 \\
4 & MFI27_6 & 0.25 & 20 & 91 & 30 \\
5 & MFI27_6 & 0.35 & 10 & 96 & 30 \\
6 & MFI27_6 & 0.35 & 10 & 90 & 15 \\
7 & MFI27_6 & 0.35 & 10 & 81 & \\
\hline
\end{tabular}

Different derivatives 1a-c, 2a,b and 3a,b using MFI27_6 catalyst (Scheme 2) of the reactants were selected in order to generalize the scope of our methodology towards Biginelli reaction. The optimization of the conditions of the reaction, where $0.35 \mathrm{~g}$ catalyst and $30 \mathrm{~Hz}$ Ball-mill frequencies were applied and the corresponding DHPM products were obtained in excellent yields were recorded (86\%-96\%, Scheme 2).

The reusability of the MFI27_6 catalyst was tested for many reaction cycles under the optimized reaction conditions. The catalyst detached upon the closure of the reaction by separation. It was then cleaned with ethyl acetate and dried under vacuum. The recovered catalyst was re-examined five times under the same operating conditions. Figure 8 shows that the re-examined catalyst had promising efficiency under the same working reaction circumstances even after five periods of re-use. 


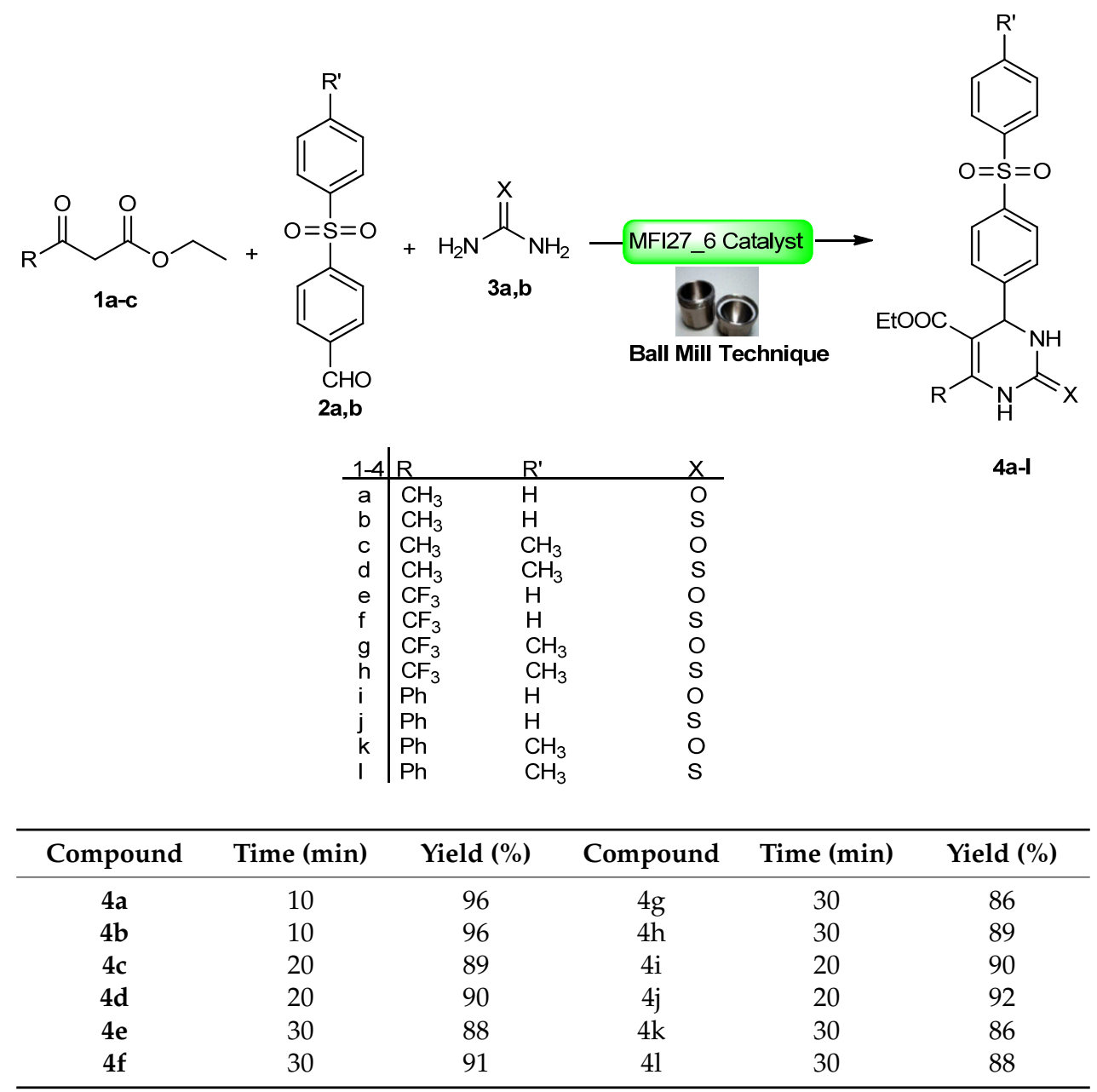

Scheme 2. The MFI27_6 catalyst catalyzed synthesis of DHPMs 4a-1 utilizing ball mill technique.

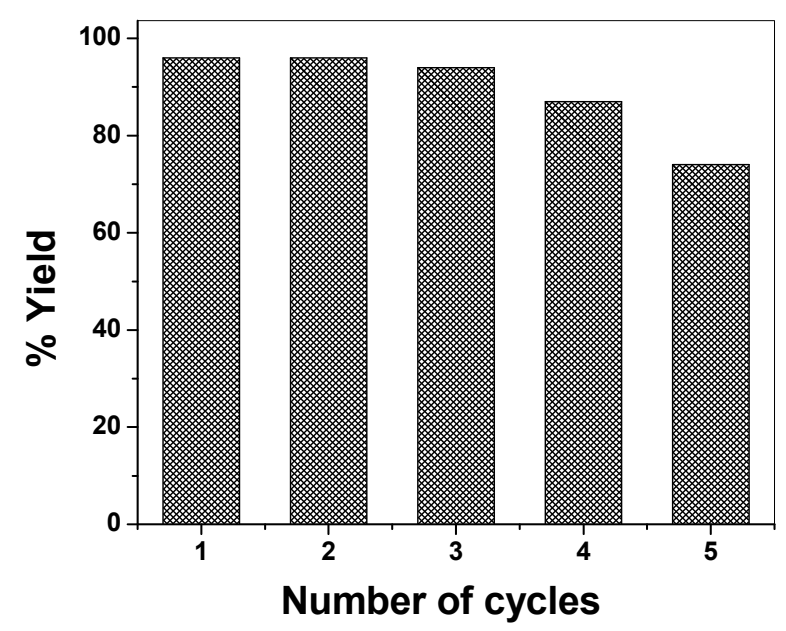

Figure 8. Re-usability of MFI27_6 catalyst.

The minor decline detected in the catalytic activity of the MFI27_6 catalyst on the fourth and fifth period could be credited to the loss of the catalyst's weight at each time of use $[49,50]$. These outcomes are representative of the robust nature of the MFI27_6 catalyst for the Biginelli reaction.

The structure of DHPM derivatives 4a-1 was assigned and found to be in line with the elemental analyses and spectral data (compare experimental part), notably, the ${ }^{19} \mathrm{~F}$ NMR spectrum 
of compounds $\mathbf{4} \mathbf{e}-\mathbf{h}$ is the key analysis for fluorine-containing compounds. Taking compound $4 \mathbf{e}$ as an example, only the signals of the trifluoromethyl group were observed in the ${ }^{19} \mathrm{~F}$ NMR spectra at $\delta$ $-61.66 \mathrm{ppm}$ (cf. experimental part).

The Biginelli reaction mechanism is a fairly contentious topic; however, it is now recognized that the reaction that leads to the creation of the DHPMs product can happen over three dissimilar paths in which the procedure starts by the development of three probable intermediates: Knoevenagel, iminium, or enamine [51]. To reveal the reaction mechanism in the presence of the MFI27_6 catalyst, time-dependent ${ }^{1} \mathrm{H}$ NMR mechanistic studies have been done in order to examine which intermediate the reaction takes over. The progress of the reaction of ethyl acetoacetate (1) with aldehyde $\mathbf{2}$ and urea (3a) was monitored by ${ }^{1} \mathrm{H}$ NMR at regular intervals of $2 \mathrm{~min}$. The ${ }^{1} \mathrm{H}$ NMR was noted (Figure 9), and a new signal at $8.62 \mathrm{ppm}$ which matched the $=\mathrm{CH}$ - grew concurrently with a decline in the intensity of the aldehyde proton signal at $9.98 \mathrm{ppm}$. Both signals disappeared after $6 \mathrm{~min}$. Time-dependent ${ }^{1} \mathrm{H}$ NMR studies suggest that the reaction occurs via the Knovenagel intermediate (Scheme 3).

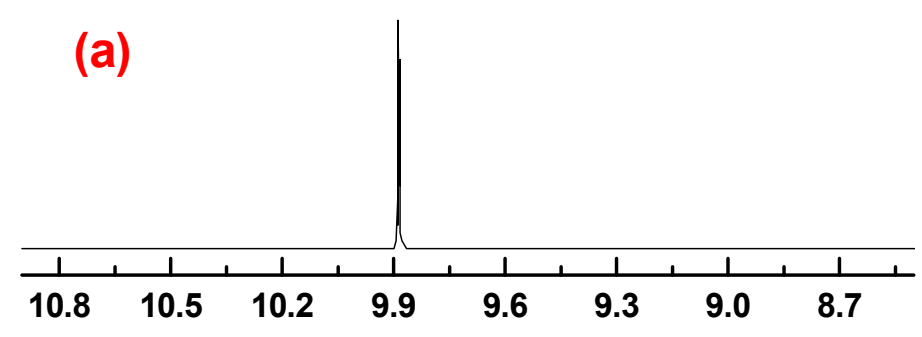

(b)

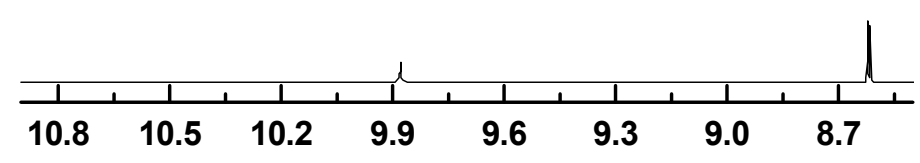

(c)

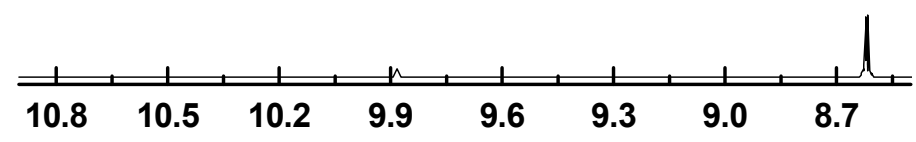

(d)

\begin{tabular}{ccccccccc}
\hline$l$ & 1 & 1 & 1 & 1 & 1 & 1 & 1 & 1 \\
\hline 10.8 & 10.5 & 10.2 & 9.9 & 9.6 & 9.3 & 9.0 & 8.7 \\
& & Chemical shift (ppm)
\end{tabular}

Figure 9. Time-dependent ${ }^{1} \mathrm{H}$ NMR spectra for Biginelli reaction, formation of 4 a. Each spectrum was recorded at regular time intervals: (a) $0 \mathrm{~min}$; (b) $2 \mathrm{~min}$; (c) $4 \mathrm{~min}$; (d) $6 \mathrm{~min}$.

Therefore, we carried out an experiment under optimum reaction settings without urea to get the Knoevenagel product (used as authentic sample for intermediate comparing TLC), then the reaction was carried under optimal conditions, where the conformation of the environment of the reaction was checked by thin layer chromatography (TLC) at regular time intervals ( $3 \mathrm{~min}$ ). A Knoevenagel adduct as well as a new product spots were detected by TLC. As the reaction proceeded, the intermediate spot 
(Knoevenagel adduct) decreased quickly until it vanished, and the new product spot increased. This finding supports the proposition that the reaction evaluated under optimal reaction conditions occurs via Knoevenagel intermediate $\mathbf{c}$ (through carbenium ion intermediate b), as shown in Scheme 3.

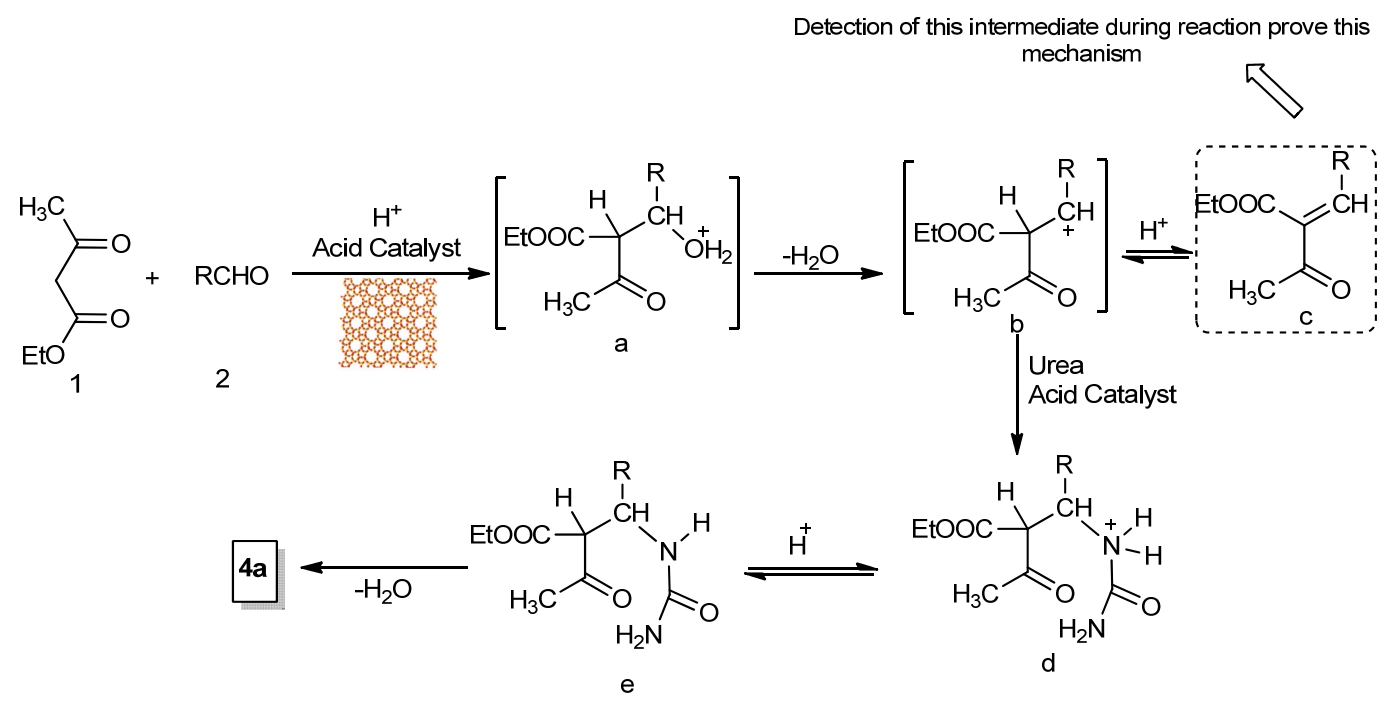

Scheme 3. Suggested mechanism for synthesis of $4 \mathbf{a}$.

The superior catalytic activity and high yield of the desired products in very short reaction time were a result of different parameters: (i) the physicochemical properties of the catalyst, i.e., their porous and acidic nature (ii) the mechano-chemical effect caused by ball mill technique during the reaction process. Alkali-treatment is another way of modifying zeolite, where the results of chemical analyses and crystallography clearly show that the alkali-treatment led to an extraction of a siliceous species from the framework of ZSM-5. It is shown from surface area measurements that the increase in the time of alkali treatment resulted in a pronounced increase in the mesopore volume/surface area and hierarchically of the alkali treated MFI27_6 catalyst. We obtained a pronounced enlargement of the external surface area due to the creation of mesopores without collapse in crystal structure of the as-received ZSM-5. The porous nature of the alkali-treated catalyst enables the reaction to occur easily instead of there are bulky groups in the reagents, due to the induced shape selectivity of the zeolite as a result of its pore widening. Accordingly, diffusion promotion through zeolite channels was improved as a result of the mesoporous nature, providing more active sites and extended high surface area upon alkaline solution treatment of ZSM-5. Notably, the high yield and very short reaction time is not only due to the solid acid catalyst but also to the ball mill technique mentioned here for chemical transformations (term mechanochemistry was coined to describe this process). According to IUPAC, a mechano-chemical reaction is defined as "a chemical reaction that is induced by the direct absorption of mechanical energy" [52]. However, the mechanochemistry is higher than the combative behavior of the materials. It is known that the powered initiation of solids leads to a rise in outer surface area, exterior energy and surface defects. The augmented superficial energy can result in a mechano-chemical initiation if changes in assembly, chemical structure or chemical reactivity happened during milling [53].

\section{Experimental}

\subsection{Materials}

Commercial ZSM-5 zeolites (ALSI PENTA, Schwandorf, Germany, SM27, $\mathrm{Si} / \mathrm{Al}=13$ ) with a nominal $\mathrm{SiO}_{2} / \mathrm{Al}_{2} \mathrm{O}_{3}$ of 27 was used as a parent zeolite. It was calcined at $550{ }^{\circ} \mathrm{C}$ for $5 \mathrm{~h}$ under the flow of synthetic air to get proton form and labelled as MFI27. 
4-(phenylsulfonyl)benzaldehyde [54] and 4-tosylbenzaldehyde [55] were prepared according to procedures in the literature.

\subsection{Alkali-Treatment of ZSM-5}

Typically, $50 \mathrm{~mL}$ of $0.2 \mathrm{M} \mathrm{NaOH}$ solution was used to treat $1.5 \mathrm{~g}$ of zeolite powder under stirring conditions. The treatment was carried out at $80^{\circ} \mathrm{C}$ for 2, $4,6 \mathrm{~h}$ and labelled as MFI27_2, MFI27_4, MFI27_6 respectively. After the treatment, the sample was quenched in an ice bath, filtered thoroughly washed with distilled water and subsequently dried at $100{ }^{\circ} \mathrm{C}$ overnight. To convert the alkali treated sample into $\mathrm{H}$-form, $1 \mathrm{~g}$ of alkali treated zeolite powder was ion-exchanged three times with $1 \mathrm{~mol} \cdot \mathrm{L}^{-1} \mathrm{NH}_{4} \mathrm{NO}_{3}$ under stirring condition for $8 \mathrm{~h}$ at $25^{\circ} \mathrm{C}$. The $\mathrm{pH}$ of the solution was adjusted at 7 with $\mathrm{NH}_{4} \mathrm{NO}_{3}$. The ion exchanged powder was filtered, washed and dried at $100{ }^{\circ} \mathrm{C}$ overnight. Subsequently the post modified sample was calcined at $550{ }^{\circ} \mathrm{C}$ for $5 \mathrm{~h}$ under the flow of synthetic air. The post-treatment commercial zeolites modified by alkali treatment are labelled as MFI27_2, MFI27_4 and MFI27_6.

\subsection{Characterization Techniques}

X'pert Pro diffractometer from Phillips Analytical was used to carry out the X-ray diffraction measurements. The diffraction patterns were obtained from. $\mathrm{Cu} \mathrm{K} \alpha$ radiation $(\lambda=1.54056 \AA)$. Concentrations of $\mathrm{Si}$ and $\mathrm{Al}$ were resolute using the inductively coupled plasma-optical emission spectrometry (ICP-OES Plasma 400, Perkin Elmer, Waltham, MA, USA). $\mathrm{N}_{2}$ physisorption measurements were performed using Quadrasorb ${ }^{\mathrm{TM}} \mathrm{SI}$ instrument (Quantachrome, Boynton Beach, FL, USA) at a temperature of $-196{ }^{\circ} \mathrm{C}$. The samples were outgassed by heating at $250{ }^{\circ} \mathrm{C}$ under extraordinary vacuity then retained at these conditions for $12 \mathrm{~h}$ prior to the adsorption/desorption measurements. Specific surface areas were calculated rendering the Brunauer-Emmet-Teller (BET) equation utilizing the adsorption isotherm. The pore size distribution (PSD) of zeolite samples was considered from an adsorption branch using the NLDFT method. The ammonia temperature programmed desorption $\left(\mathrm{NH}_{3}-\mathrm{TPD}\right)$ of untreated zeolite and that treated with alkali was measured using TPDRO 1100 Thermo-electron corporation (Thermo Fisher Scientific, Cambridge, UK). The sample was placed between the layers of quartz wool in a glass tube and then pre-treated in the helium flow at $550{ }^{\circ} \mathrm{C}$ for $30 \mathrm{~min}$ with a ramp of $10^{\circ} \mathrm{C} / \mathrm{min}$. The saturation of zeolite sample with gaseous ammonia was carried out at $120^{\circ} \mathrm{C}$ for $30 \mathrm{~min}$. Finally, the ammonia was removed in the helium flow at $600{ }^{\circ} \mathrm{C}$ for $60 \mathrm{~min}$ with a ramp of $10^{\circ} \mathrm{C} / \mathrm{min}$. The gas coming out of the glass tube was analyzed by a thermal conductivity detector (TCD). Diffuse Reflectance Infrared Fourier Transform (DRIFT) spectra were collected at ambient temperature using the Perkin-Elmer Spectrum 100 FTIR spectrometer (PerkinElmer, Waltham, MA, USA). The catalysts were exposed to the adsorption of pyridine and the analysis was carried out over a catalyst disk which was treated at $100{ }^{\circ} \mathrm{C}$ under vacuum for $5 \mathrm{~h}$. Later, the sample was exposed to pyridine vapor and finally roasted at $100{ }^{\circ} \mathrm{C}$ under vacuum for $30 \mathrm{~min}$ prior to each measurement.

\subsection{Characterizations of the Reaction Products}

A Gallenkamp melting point apparatus was utilized in order to determine the melting points of manufactured products. Spectral data from infrared for the compounds were verified utilizing (Perkin Elmer SP 100, PerkinElmer) infrared spectrophotometer. The ${ }^{1} \mathrm{H}$ NMR, ${ }^{13} \mathrm{C}$ NMR and ${ }^{19} \mathrm{~F}$ NMR spectra were recorded on a Bruker WM $600 \mathrm{MHz}$ spectrometer (Bruker, Billerica, MA, USA), respectively using Tetramethylsilane (TMS) $(0.00 \mathrm{ppm})$. The deuterated solvent sign was selected as internal standard. The chemical shifts ( $\delta)$ in ppm comparative to TMS signal as reference, and coupling constant in Hz. Shimadzu GCMS-QP 1000 EX mass spectrometer (Shimadzu Corp., Kyoto, Japan) at $70 \mathrm{eV}$ was applied to record the mass spectra. (C, H, N and S) analyses were occurred at the Micro analytical Canter of Cairo University, Giza, Egypt, the data matched the pre-calculated values $( \pm 0.3 \%)$. Ball milling experiments were carried out using a $\mathrm{RETSCH}^{\mathrm{TM}}$ ball mill (cryo mill model 
without cryogenic grinding, Retsch $\mathrm{GmbH}$, Haan, Germany) utilizing a $25 \mathrm{~mL}$ stainless steel gar and two $12 \mathrm{~mm}$ stainless steel balls.

\subsection{Typical Procedure for the Catalytic Test Reaction}

MFI27 catalysts $(0.35 \mathrm{~g})$, were added to $\beta$-ketoester derivatives 1a-c $(1 \mathrm{a}: 0.65 \mathrm{~g}, \mathbf{1 b}: 0.92 \mathrm{~g}, \mathbf{1 c}$ : $0.96 \mathrm{~g})(5 \mathrm{mmol})$, benzadehyde derivatives $2 \mathbf{a}, \mathbf{b}(2 \mathbf{a}: 1.23 \mathrm{~g}, \mathbf{2 b}: 1.3 \mathrm{~g})(5 \mathrm{mmol})$ and urea derivatives 3a,b (3a: $0.36 \mathrm{~g}, 3 \mathbf{b}: 0.46 \mathrm{~g})(6 \mathrm{mmol})$ in a mortar, the grinded blend, utilizing a pestle at ambient temperature, inserted in the $25 \mathrm{~mL}$ stainless steel jar equipped with two stainless steel balls $(15 \mathrm{~mm}$ in diameter). The jar was locked and milling was carried out at the frequency illustrated in Table 3. After $3 \mathrm{~min}$, thin layer chromatography (TLC) was applied to follow up the reaction progress. If necessary, the milling cycle was repeated until the reaction was complete. The product was isolated by simple washing of the crude reaction residue with hot ethyl acetate and sonicated for 5 min to desorb all adsorbed product on the surface of catalyst then remove the catalyst by filtration. Pure solid products (4a-1) in excellent yield, after ethyl acetate removal under reduced pressure, were obtained.

Washing of the pre-used catalyst with ethyl acetate and drying prior to new catalytic test was systematically followed. Compound 4a was attained utilizing different MFI-catalysts (MF127_P, MF127_2, MF127_4 and MF127_6) using ball mill technique. All the tested catalysts showed reasonable efficiency but MF127_6 provided absurd effectiveness with high yield in dumpy period (Table 2).

Physical and spectral data of the title compounds $\mathbf{4 a - 1}$ are listed below:

Ethyl 6-methyl-2-oxo-4-(4-(phenylsulfonyl)phenyl)-1,2,3,4-tetrahydropyrimidine-5-carboxylate (4a). m.p. 271-273 ${ }^{\circ} \mathrm{C}$; IR (KBr) $v / \mathrm{cm}^{-1}: 3218(\mathrm{NH}), 1735,1680(\mathrm{CO}), 1310,1145\left(\mathrm{SO}_{2}\right) ;{ }^{1} \mathrm{H}$ NMR $\left(\mathrm{DMSO}-d_{6}\right): \delta$ $1.16\left(\mathrm{t}, J=6.8 \mathrm{~Hz}, 3 \mathrm{H}, \mathrm{CH}_{3}\right.$ ester), $2.36\left(\mathrm{~s}, 3 \mathrm{H}, \mathrm{CH}_{3}\right), 4.08\left(\mathrm{q}, J=6.8 \mathrm{~Hz}, 2 \mathrm{H}, \mathrm{CH}_{2}\right.$ ester), $5.41(\mathrm{~s}, 1 \mathrm{H}$, CH-pyrimidine), $5.53\left(\mathrm{~s}, 1 \mathrm{H}, \mathrm{NH}, \mathrm{D}_{2} \mathrm{O}\right.$ exchangeable), 6.73-7.32 (m, 7H, ArH), 7.57 (s, 1H, NH, $\mathrm{D}_{2} \mathrm{O}$ exchangeable), 7.89-7.96 (m, 2H, ArH); ${ }^{13} \mathrm{C}-\mathrm{NMR}$ (DMSO- $\left.d_{6}\right): \delta 19.29\left(\mathrm{CH}_{3}\right.$ ester), $22.99\left(\mathrm{CH}_{3}\right), 59.19$ (C-4), 64.40 ( $\mathrm{CH}_{2}$ ester), 104.48 (C-5), 128.17 (Cph), 128.25(Cph), 131.47 (Cph), 132.47 (Cph), 133.60 (Cph), 141.91 (Cph), 147.58 (Cph), 150.09 (C-6), 153.57 (Cph), 157.37 (C-2), 170.55 (CO ester); MS: $400\left(\mathrm{M}^{+}\right)$; Anal. calcd. for $\mathrm{C}_{20} \mathrm{H}_{20} \mathrm{~N}_{2} \mathrm{O}_{5} \mathrm{~S}$ (\%): C 59.99, H 5.03, N 7.00, S 8.01 Found: C 60.21, H 4.99, N 6.89, S 7.94 .

Ethyl 6-methyl-4-(4-(phenylsulfonyl)phenyl)-2-thioxo-1,2,3,4-tetrahydropyrimidine-5-carboxylate (4b). m.p. 259-261 ${ }^{\circ} \mathrm{C}$; IR (KBr) $v / \mathrm{cm}^{-1}$ : $3211(\mathrm{NH}), 1729,1684(\mathrm{CO}), 1306,1145\left(\mathrm{SO}_{2}\right) ;{ }^{1} \mathrm{H}$ NMR $\left(\mathrm{DMSO}-d_{6}\right): \delta$ $1.17\left(\mathrm{t}, J=7.2 \mathrm{~Hz}, 3 \mathrm{H}, \mathrm{CH}_{3}\right.$ ester), $2.37\left(\mathrm{~s}, 3 \mathrm{H}, \mathrm{CH}_{3}\right), 4.11\left(\mathrm{q}, J=7.2 \mathrm{~Hz}, 2 \mathrm{H}, \mathrm{CH}_{2}\right.$ ester), $5.41(\mathrm{~s}, 1 \mathrm{H}$, CH-pyrimidine), $6.95\left(\mathrm{~s}, 1 \mathrm{H}, \mathrm{NH}, \mathrm{D}_{2} \mathrm{O}\right.$ exchangeable), 7.28-7.36 (m, 7H, ArH), $7.48\left(\mathrm{~s}, 1 \mathrm{H}, \mathrm{NH}, \mathrm{D}_{2} \mathrm{O}\right.$ exchangeable), 7.77-7.86 (m, 2H, ArH); ${ }^{13} \mathrm{C}-\mathrm{NMR}$ (DMSO- $\left.d_{6}\right): \delta 13.98\left(\mathrm{CH}_{3}\right.$ ester), $17.13\left(\mathrm{CH}_{3}\right), 53.99$ (C-4), $59.56\left(\mathrm{CH}_{2}\right.$ ester), 100.66 (C-5), 126.35 (Cph),127.66 (Cph), $128.11(\mathrm{Cph}), 128.54(\mathrm{Cph}), 128.86$ (Cph), 143.45 (Cph), 145.01(Cph), 151.81 (C-6), 165.09 (Cph), 174.17 (CO ester), 183.79 (C-2); MS: 416 $\left(\mathrm{M}^{+}\right)$; Anal. calcd. for $\mathrm{C}_{20} \mathrm{H}_{20} \mathrm{~N}_{2} \mathrm{O}_{4} \mathrm{~S}_{2}$ (\%): C 57.67, H 4.84, N 6.73, $\mathrm{S} 15.40$ Found: C 57.92, H 4.79, N 6.61, S 15.32.

Ethyl 6-methyl-2-oxo-4-(4-tosylphenyl)-1,2,3,4-tetrahydropyrimidine-5-carboxylate (4c). m.p. $290-292{ }^{\circ} \mathrm{C}$; IR $(\mathrm{KBr}) v / \mathrm{cm}^{-1}: 3221(\mathrm{NH}), 1723,1687(\mathrm{CO}), 1310,1149\left(\mathrm{SO}_{2}\right) ;{ }^{1} \mathrm{H}$ NMR $\left(\mathrm{DMSO}-d_{6}\right): \delta 1.14(\mathrm{t}, J=6.8 \mathrm{~Hz}$, $3 \mathrm{H}, \mathrm{CH}_{3}$ ester), $2.37\left(\mathrm{~s}, 3 \mathrm{H}, \mathrm{CH}_{3}\right), 2.41\left(\mathrm{~s}, 3 \mathrm{H}, \mathrm{CH}_{3}\right), 4.17$ (q, $J=6.8 \mathrm{~Hz}, 2 \mathrm{H}, \mathrm{CH}_{2}$ ester), $5.34(\mathrm{~s}, 1 \mathrm{H}$, CH-pyrimidine), 6.49 (s, 1H, NH, $\mathrm{D}_{2} \mathrm{O}$ exchangeable), 7.07-7.79 (m, 8H, ArH), $7.59\left(\mathrm{~s}, 1 \mathrm{H}, \mathrm{NH}, \mathrm{D}_{2} \mathrm{O}\right.$ exchangeable), ${ }^{13} \mathrm{C}-\mathrm{NMR}$ (DMSO- $\left.d_{6}\right): \delta 13.62\left(\mathrm{CH}_{3}\right.$ ester), $17.06\left(\mathrm{CH}_{3}\right), 20.68\left(\mathrm{CH}_{3}\right.$-tosyl), $53.85(\mathrm{C}-4)$, $60.12\left(\mathrm{CH}_{2}\right.$ ester), 103.41 (C-5), 127.31 (Cph), $127.56(\mathrm{Cph}), 128.47$ (Cph), 131.56 (Cph), 139.52 (Cph), 140.81 (Cph), 141.06 (Cph), 145.83 (C-6), 150.69 (Cph), 160.15 (C-2), 174.00 (CO ester); MS: $414\left(\mathrm{M}^{+}\right.$); Anal. calcd. for $\mathrm{C}_{21} \mathrm{H}_{22} \mathrm{~N}_{2} \mathrm{O}_{5} \mathrm{~S}$ (\%): C 60.85, H 5.35, N 6.76, S 7.74 Found: C 61.07, H 5.31, N 6.66, S 7.66.

Ethyl 6-methyl-2-thioxo-4-(4-tosylphenyl)-1,2,3,4-tetrahydropyrimidine-5-carboxylate (4d). m.p. 282-284 ${ }^{\circ} \mathrm{C}$; IR (KBr) $v / \mathrm{cm}^{-1}$ : $3204(\mathrm{NH}), 1731,1685(\mathrm{CO}), 1314,1145\left(\mathrm{SO}_{2}\right) ;{ }^{1} \mathrm{H}$ NMR (DMSO-d $\left.d_{6}\right): \delta 1.09$ 
$\left(\mathrm{t}, J=6.8 \mathrm{~Hz}, 3 \mathrm{H}, \mathrm{CH}_{3}\right.$ ester), $2.33\left(\mathrm{~s}, 3 \mathrm{H}, \mathrm{CH}_{3}\right), 2.48\left(\mathrm{~s}, 3 \mathrm{H}, \mathrm{CH}_{3}\right), 4.23\left(\mathrm{q}, J=6.8 \mathrm{~Hz}, 2 \mathrm{H}, \mathrm{CH}_{2}\right.$ ester), $5.36\left(\mathrm{~s}, 1 \mathrm{H}, \mathrm{CH}\right.$-pyrimidine), $6.58\left(\mathrm{~s}, 1 \mathrm{H}, \mathrm{NH}, \mathrm{D}_{2} \mathrm{O}\right.$ exchangeable), 7.09-7.74 $(\mathrm{m}, 8 \mathrm{H}, \mathrm{ArH}), 7.61(\mathrm{~s}, 1 \mathrm{H}$, $\mathrm{NH}, \mathrm{D}_{2} \mathrm{O}$ exchangeable); ${ }^{13} \mathrm{C}-\mathrm{NMR}$ (DMSO- $\left.d_{6}\right): \delta 13.82\left(\mathrm{CH}_{3}\right.$ ester), $17.54\left(\mathrm{CH}_{3}\right), 19.98\left(\mathrm{CH}_{3}\right.$-tosyl), 55.05 (C-4), $59.72\left(\mathrm{CH}_{2}\right.$ ester), 101.47 (C-5), 126.74 (Cph), 127.92 (Cph), $128.02(\mathrm{Cph}), 130.93$ (Cph), 139.86 (Cph), 141.85 (Cph), 142.03 (Cph), 147.56 (C-6), 158.41 (Cph), 166.53 (CO ester), 178.10 (C-2); MS: $430\left(\mathrm{M}^{+}\right)$; Anal. calcd. for $\mathrm{C}_{21} \mathrm{H}_{22} \mathrm{~N}_{2} \mathrm{O}_{4} \mathrm{~S}_{2}$ (\%): C 58.58, H 5.15, N 6.51, S 14.90 Found: C 58.82, H 5.09, N 6.40, S 14.83 .

Ethyl 2-oxo-4-(4-(phenylsulfonyl)phenyl)-6-(trifluoromethyl)-1,2,3,4-tetrahydropyrimidine-5-carboxylate (4e). m.p. $218-220{ }^{\circ} \mathrm{C} ; \mathrm{IR}(\mathrm{KBr}) v / \mathrm{cm}^{-1}: 3216(\mathrm{NH}), 1723,1688(\mathrm{CO}), 1310,1142\left(\mathrm{SO}_{2}\right) ;{ }^{1} \mathrm{H} \mathrm{NMR}\left(\mathrm{CDCl}_{3}\right)$ : $\delta 1.16\left(\mathrm{t}, J=6.8 \mathrm{~Hz}, 3 \mathrm{H}, \mathrm{CH}_{3}\right.$ ester), $4.07\left(\mathrm{q}, J=6.8 \mathrm{~Hz}, 2 \mathrm{H}, \mathrm{CH}_{2}\right.$ ester), 5.39 (s, $1 \mathrm{H}, \mathrm{CH}$-pyrimidine), $6.29\left(\mathrm{~s}, 1 \mathrm{H}, \mathrm{NH}, \mathrm{D}_{2} \mathrm{O}\right.$ exchangeable), 6.99-7.29 (m, 4H, ArH), 7.99-8.06 (m, 5H, ArH), $8.69(\mathrm{~s}, 1 \mathrm{H}, \mathrm{NH}$, $\mathrm{D}_{2} \mathrm{O}$ exchangeable $) ;{ }^{13} \mathrm{C}-\mathrm{NMR}\left(\mathrm{CDCl}_{3}\right): \delta 14.16\left(\mathrm{CH}_{3}\right.$ ester $), 54.92(\mathrm{C}-4), 60.11\left(\mathrm{CH}_{2}\right.$ ester $), 101.22(\mathrm{C}-5)$, $121.88\left(\mathrm{CF}_{3}\right), 128.26$ (Cph), $128.34(\mathrm{Cph}), 128.71(\mathrm{Cph}), 128.80$ (Cph), $133.70(\mathrm{Cph}), 139.64(\mathrm{Cph}), 139.67$ (C-6), 146.49 (Cph), 153.74 (Cph), 163.52 (C-2), 165.55 (CO ester); ${ }^{19} \mathrm{~F}$ NMR $\left(\mathrm{CDCl}_{3}\right)$ : $\delta$-61.66; MS: $454\left(\mathrm{M}^{+}\right)$; Anal. calcd. for $\mathrm{C}_{20} \mathrm{H}_{17} \mathrm{~F}_{3} \mathrm{~N}_{2} \mathrm{O}_{5} \mathrm{~S}$ (\%): C 52.86, H 3.77, N 6.16, $\mathrm{S}$ 7.06 Found: C 53.12, H 3.69, N 6.05, S 6.99.

Ethyl 4-(4-(phenylsulfonyl)phenyl)-2-thioxo-6-(trifluoromethyl)-1,2,3,4-tetrahydropyrimidine-5-carboxylate (4f). m.p. 199-201 ${ }^{\circ} \mathrm{C}$; IR (KBr) v/ $\mathrm{cm}^{-1}$ : $3227(\mathrm{NH}), 1731,1686$ (CO), 1310, $1145\left(\mathrm{SO}_{2}\right) ;{ }^{1} \mathrm{H}$ NMR (DMSO- $\left.d_{6}\right): \delta 1.01\left(\mathrm{t}, J=7.0 \mathrm{~Hz}, 3 \mathrm{H}, \mathrm{CH}_{3}\right.$ ester), $3.92\left(\mathrm{q}, J=7.0 \mathrm{~Hz}, 2 \mathrm{H}, \mathrm{CH}_{2}\right.$ ester), $5.09(\mathrm{~d}, 1 \mathrm{H}$, CH-pyrimidine), 7.12-7.31 (m, 5H, ArH), $7.78(\mathrm{~d}, 2 \mathrm{H}, \mathrm{ArH}), 8.21(\mathrm{~d}, 2 \mathrm{H}, \mathrm{ArH}), 9.55\left(\mathrm{~s}, 1 \mathrm{H}, \mathrm{NH}, \mathrm{D}_{2} \mathrm{O}\right.$ exchangeable), $10.24\left(\mathrm{~s}, 1 \mathrm{H}, \mathrm{NH}, \mathrm{D}_{2} \mathrm{O}\right.$ exchangeable); ${ }^{13} \mathrm{C}-\mathrm{NMR}$ (DMSO- $\left.d_{6}\right): \delta 14.63\left(\mathrm{CH}_{3}\right.$ ester), 54.67 (C-4), $60.21\left(\mathrm{CH}_{2}\right.$ ester), $101.37(\mathrm{C}-5), 121.56\left(\mathrm{CF}_{3}\right), 127.01$ (Cph), 128.36 (Cph), $129.18(\mathrm{Cph}), 129.96$ (Cph), 132.15 (Cph), 139.52 (Cph), 140.01 (Cph), 145.64 (Cph), 153.12 (C-6), 165.76 (CO ester), 174.89 (C-2); ${ }^{19}$ F NMR (DMSO- $d_{6}$ ): $\delta$-61.52; MS: $470\left(\mathrm{M}^{+}\right)$; Anal. calcd. for $\mathrm{C}_{20} \mathrm{H}_{17} \mathrm{~F}_{3} \mathrm{~N}_{2} \mathrm{O}_{4} \mathrm{~S}_{2}(\%)$ : C 51.06, $\mathrm{H}$ 3.64, N 5.95, S 13.63 Found: C 51.30, H 3.59, N 5.87, S 13.52 .

Ethyl 2-oxo-4-(4-tosylphenyl)-6-(trifluoromethyl)-1,2,3,4-tetrahydropyrimidine-5-carboxylate (4g). m.p. 219-221 ${ }^{\circ} \mathrm{C}$; IR (KBr) v/cm ${ }^{-1}: 3222(\mathrm{NH}), 1729,1681(\mathrm{CO}), 1312,1145\left(\mathrm{SO}_{2}\right) ;{ }^{1} \mathrm{H}$ NMR $\left(\mathrm{CDCl}_{3}\right)$ : $\delta 1.12\left(\mathrm{t}, J=6.8 \mathrm{~Hz}, 3 \mathrm{H}, \mathrm{CH}_{3}\right.$ ester $), 2.46\left(\mathrm{~s}, 3 \mathrm{H}, \mathrm{CH}_{3}\right), 4.17\left(\mathrm{q}, J=6.8 \mathrm{~Hz}, 2 \mathrm{H}, \mathrm{CH}_{2}\right.$ ester $), 5.21(\mathrm{~s}, 1 \mathrm{H}$, $\mathrm{CH}$-pyrimidine), 6.40 (s, 1H, NH, $\mathrm{D}_{2} \mathrm{O}$ exchangeable), 6.94-7.21 (m, 4H, ArH), 7.79-7.95 (m, 4H, ArH), $8.24\left(\mathrm{~s}, 1 \mathrm{H}, \mathrm{NH}, \mathrm{D}_{2} \mathrm{O}\right.$ exchangeable); ${ }^{13} \mathrm{C}-\mathrm{NMR}\left(\mathrm{CDCl}_{3}\right): \delta 14.23\left(\mathrm{CH}_{3}\right.$ ester $), 19.35\left(\mathrm{CH}_{3}\right.$ tosyl $), 54.16$ (C-4), $60.61\left(\mathrm{CH}_{2}\right.$ ester), $102.00(\mathrm{C}-5), 121.19\left(\mathrm{CF}_{3}\right), 127.96(\mathrm{Cph}), 128.21(\mathrm{Cph}), 128.36(\mathrm{Cph}), 129.47$ (Cph), 133.98 (Cph), 139.59 (Cph), 140.62 (C-6), 147.08 (Cph), 151.05 (Cph), 157.96 (C-2), 167.35 (C-ester); ${ }^{19} \mathrm{~F}$ NMR $\left(\mathrm{CDCl}_{3}\right): \delta-61.54$; MS: $468\left(\mathrm{M}^{+}\right)$; Anal. calcd. for $\mathrm{C}_{21} \mathrm{H}_{19} \mathrm{~F}_{3} \mathrm{~N}_{2} \mathrm{O}_{5} \mathrm{~S}(\%)$ : C 53.84, $\mathrm{H} 4.09$, N 5.98, S 6.84 Found: C 54.06, H 4.04, N 5.88, S 6.77.

Ethyl 2-thioxo-4-(4-tosylphenyl)-6-(trifluoromethyl)-1,2,3,4-tetrahydropyrimidine-5-carboxylate (4h). m.p. 211-213 ${ }^{\circ} \mathrm{C}$; IR (KBr) $v / \mathrm{cm}^{-1}: 3221(\mathrm{NH}), 1734,1685(\mathrm{CO}), 1312,1145\left(\mathrm{SO}_{2}\right) ;{ }^{1} \mathrm{H}$ NMR (DMSO-d $\left.d_{6}\right)$ : $1.02\left(\mathrm{t}, J=6.8 \mathrm{~Hz}, 3 \mathrm{H}, \mathrm{CH}_{3}\right.$ ester), $2.21\left(\mathrm{~s}, 3 \mathrm{H}, \mathrm{CH}_{3}\right), 3.94\left(\mathrm{q}, J=6.8 \mathrm{~Hz}, 2 \mathrm{H}, \mathrm{CH}_{2}\right.$ ester $), 5.09(\mathrm{~s}, 1 \mathrm{H}$, CH-pyrimidine), $7.28(\mathrm{~m}, 4 \mathrm{H}, \mathrm{ArH}), 7.87(\mathrm{~m}, 4 \mathrm{H}, \mathrm{ArH}), 9.58\left(\mathrm{~s}, 1 \mathrm{H}, \mathrm{NH}, \mathrm{D}_{2} \mathrm{O}\right.$ exchangeable), 10.30 (s, $1 \mathrm{H}, \mathrm{NH}, \mathrm{D}_{2} \mathrm{O}$ exchangeable); ${ }^{13} \mathrm{C}-\mathrm{NMR}$ (DMSO- $\left.d_{6}\right): \delta 14.63\left(\mathrm{CH}_{3}\right.$ ester), $17.80\left(\mathrm{CH}_{3}\right.$ tosyl), 54.07 (C-4), 60.28 ( $\mathrm{CH}_{2}$ ester), 100.91 (C-5), $128.94\left(\mathrm{CF}_{3}\right), 129.23$ (Cph), 129.86 (Cph), $129.99(\mathrm{Cph}), 132.88$ (Cph), 139.54 (Cph), 143.60 (Cph), 146.01 (Cph), 152.89 (C-6), 165.61 (CO ester), 174.87 (C-2); ${ }^{19} \mathrm{~F}$ NMR (DMSO- $d_{6}$ ): $\delta-61.57$; MS: $484\left(\mathrm{M}^{+}\right)$; Anal. calcd. for $\mathrm{C}_{21} \mathrm{H}_{19} \mathrm{~F}_{3} \mathrm{~N}_{2} \mathrm{O}_{4} \mathrm{~S}_{2}(\%)$ : C 52.06, H 3.95, N 5.78, S 13.24 Found: C 52.27, H 3.92, N 5.68, S 13.16.

Ethyl 2-oxo-6-phenyl-4-(4-(phenylsulfonyl)phenyl)-1,2,3,4-tetrahydropyrimidine-5-carboxylate (4i). m.p. 219-222 ${ }^{\circ} \mathrm{C}$; IR (KBr) v/ $\mathrm{cm}^{-1}: 3228(\mathrm{NH}), 1725,1689(\mathrm{CO}), 1310,1148\left(\mathrm{SO}_{2}\right) ;{ }^{1} \mathrm{H}$ NMR $\left(\mathrm{CDCl}_{3}\right)$ : $\delta 1.19\left(\mathrm{t}, J=7.2 \mathrm{~Hz}, 3 \mathrm{H}, \mathrm{CH}_{3}\right.$ ester), 4.17 (q, $J=7.2 \mathrm{~Hz}, 2 \mathrm{H}, \mathrm{CH}_{2}$ ester), 5.32 (s, 1H, CH-pyrimidine), $6.02\left(\mathrm{~s}, 1 \mathrm{H}, \mathrm{NH}, \mathrm{D}_{2} \mathrm{O}\right.$ exchangeable), 6.99-7.47 (m, 9H, ArH), 7.84-8.03 (m, 5H, ArH), $8.41(\mathrm{~s}, 1 \mathrm{H}$, $\mathrm{NH}, \mathrm{D}_{2} \mathrm{O}$ exchangeable); ${ }^{13} \mathrm{C}-\mathrm{NMR}\left(\mathrm{CDCl}_{3}\right): \delta 14.35\left(\mathrm{CH}_{3}\right.$ ester $), 54.02(\mathrm{C}-4), 60.47\left(\mathrm{CH}_{2}\right.$ ester $), 101.89$ 
(C-5), 126.12 (Cph), 126.85 (Cph), 127.56 (Cph), 128.03 (Cph), 128.30 (Cph), 128.69 (Cph), 129.41 (Cph), 131.45 (Cph), 134.51 (Cph), 139.60 (Cph), 141.55 (C-6), 141.95 (Cph), 147.58 (Cph), 150.12 (C-2), 167.32 (CO ester); MS: 462( $\left.\mathrm{M}^{+}\right)$; Anal. calcd. for $\mathrm{C}_{25} \mathrm{H}_{22} \mathrm{~N}_{2} \mathrm{O}_{5} \mathrm{~S}$ (\%): $\mathrm{C} 64.92, \mathrm{H} 4.79, \mathrm{~N}$ 6.06, $\mathrm{S} 6.93$ Found: $\mathrm{C}$ 65.18, H 4.73, N 5.94, S 6.85 .

Ethyl 6-phenyl-4-(4-(phenylsulfonyl)phenyl)-2-thioxo-1,2,3,4-tetrahydropyrimidine-5-carboxylate (4j). m.p. 178-180 ${ }^{\circ} \mathrm{C}$; IR (KBr) $v / \mathrm{cm}^{-1}: 3219(\mathrm{NH}), 1725,1682(\mathrm{CO}), 1315,1149\left(\mathrm{SO}_{2}\right) ;{ }^{1} \mathrm{H}$ NMR (DMSO-d 6 ): $\delta 0.91\left(\mathrm{t}, J=7.2 \mathrm{~Hz}, 3 \mathrm{H}, \mathrm{CH}_{3}\right.$ ester), $3.83\left(\mathrm{q}, J=7.2 \mathrm{~Hz}, 2 \mathrm{H}, \mathrm{CH}_{2}\right.$ ester), 5.36 (s, $1 \mathrm{H}, \mathrm{CH}$-pyrimidine), 6.75-7.06 (m, 9H, ArH), 7.62-8.13 (m, 5H, ArH), $9.45\left(\mathrm{~s}, 1 \mathrm{H}, \mathrm{NH}, \mathrm{D}_{2} \mathrm{O}\right.$ exchangeable), $10.15(\mathrm{~s}, 1 \mathrm{H}, \mathrm{NH}$, $\mathrm{D}_{2} \mathrm{O}$ exchangeable); ${ }^{13} \mathrm{C}-\mathrm{NMR}$ (DMSO- $\left.d_{6}\right): \delta 14.46\left(\mathrm{CH}_{3}\right.$ ester), $51.31(\mathrm{C}-4), 60.13\left(\mathrm{CH}_{2}\right.$ ester $), 101.62$ (C-5), 127.25 (Cph), 127.78 (Cph), 128.25 (Cph), 129.78 (Cph), 129.98 (Cph), 130.01 (Cph), 130.12 (Cph), 130.78 (Cph), 135.64 (Cph), 139.60 (Cph), 142.86 (Cph), 145.45 (Cph), 150.02 (C-6), 165.70 (CO ester), 174.03 (C-2); MS: 478(M+); Anal. calcd. for $\mathrm{C}_{25} \mathrm{H}_{22} \mathrm{~N}_{2} \mathrm{O}_{4} \mathrm{~S}_{2}$ (\%): C 62.74, H 4.63, N 5.85, S 13.40 Found: C $62.98, \mathrm{H} 4.59, \mathrm{~N} 5.74, \mathrm{~S} 13.31$.

Ethyl 2-oxo-6-phenyl-4-(4-tosylphenyl)-1,2,3,4-tetrahydropyrimidine-5-carboxylate (4k). m.p. 262-264 ${ }^{\circ} \mathrm{C}$; IR $(\mathrm{KBr}) v / \mathrm{cm}^{-1}: 3218(\mathrm{NH}), 1735,1681(\mathrm{CO}), 1310,1143\left(\mathrm{SO}_{2}\right) ;{ }^{1} \mathrm{H}$ NMR $\left(\mathrm{DMSO}-d_{6}\right): \delta 1.17(\mathrm{t}, J=6.8 \mathrm{~Hz}$, $3 \mathrm{H}, \mathrm{CH}_{3}$ ester), 2.39 (s, 3H, $\left.\mathrm{CH}_{3}\right), 4.11$ (q, $J=6.8 \mathrm{~Hz}, 2 \mathrm{H}, \mathrm{CH}_{2}$ ester), 5.28 (s, $1 \mathrm{H}, \mathrm{CH}$-pyrimidine), $6.14\left(\mathrm{~s}, 1 \mathrm{H}, \mathrm{NH}, \mathrm{D}_{2} \mathrm{O}\right.$ exchangeable), 6.92-7.33 (m, 9H, ArH), 7.69-7.92 (m, 4H, ArH), $8.26(\mathrm{~s}, 1 \mathrm{H}, \mathrm{NH}$, $\mathrm{D}_{2} \mathrm{O}$ exchangeable); ${ }^{13} \mathrm{C}-\mathrm{NMR}$ (DMSO- $\left.d_{6}\right): \delta 14.22\left(\mathrm{CH}_{3}\right.$ ester), $20.16\left(\mathrm{CH}_{3}\right.$ tosyl), 53.51 (C-4), 61.45 ( $\mathrm{CH}_{2}$ ester), 103.45 (C-5), 126.69 (Cph), 126.85 (Cph), 127.89 (Cph), $128.56(\mathrm{Cph}), 128.69(\mathrm{Cph}), 128.88$ (Cph), 129.96 (Cph), 131.48 (Cph), 135.78 (Cph), 139.02 (Cph), 142.45 (C-6), 142.99 (Cph), 148.25 (Cph), 156.10 (C-2), 168.13 (CO ester); MS: $476\left(\mathrm{M}^{+}\right)$; Anal. calcd. for $\mathrm{C}_{26} \mathrm{H}_{24} \mathrm{~N}_{2} \mathrm{O}_{5} \mathrm{~S}$ (\%): C 65.53, H 5.08, N 5.88, S 6.73 Found: C 65.75, H 5.06, N 5.75, S 6.66.

Ethyl 6-phenyl-2-thioxo-4-(4-tosylphenyl)-1,2,3,4-tetrahydropyrimidine-5-carboxylate (4l). m.p. 236-238 ${ }^{\circ} \mathrm{C}$; IR (KBr) $v / \mathrm{cm}^{-1}: 3217(\mathrm{NH}), 1735,1685(\mathrm{CO}), 1312,1145\left(\mathrm{SO}_{2}\right) ;{ }^{1} \mathrm{H}$ NMR (DMSO-d 6 ): $\delta 1.01$ $\left(\mathrm{t}, J=6.8 \mathrm{~Hz}, 3 \mathrm{H}, \mathrm{CH}_{3}\right.$ ester $), 2.21\left(\mathrm{~s}, 3 \mathrm{H}, \mathrm{CH}_{3}\right), 3.92\left(\mathrm{q}, J=6.8 \mathrm{~Hz}, 2 \mathrm{H}, \mathrm{CH}_{2}\right.$ ester $), 5.16(\mathrm{~s}, 1 \mathrm{H}$, CH-pyrimidine), 6.75-7.78 (m, 7H, ArH), 8.01-8.23 (m, 2H, ArH), $9.63\left(\mathrm{~s}, 1 \mathrm{H}, \mathrm{NH}, \mathrm{D}_{2} \mathrm{O}\right.$ exchangeable), $10.36\left(\mathrm{~s}, 1 \mathrm{H}, \mathrm{NH}, \mathrm{D}_{2} \mathrm{O}\right.$ exchangeable); ${ }^{13} \mathrm{C}-\mathrm{NMR}$ (DMSO- $\left.d_{6}\right): \delta 14.60\left(\mathrm{CH}_{3}\right.$ ester), $17.86\left(\mathrm{CH}_{3}\right.$ tosyl), 54.45 (C-4), 60.41 ( $\mathrm{CH}_{2}$ ester), 100.42 (C-5), 111.12 (Cph), 121.34 (Cph), 126.86 (Cph), 128.27 (Cph), 128.79 (Cph), 128.93 (Cph), 132.88 (Cph), 136.00 (Cph), 138.11 (Cph), 139.85 (Cph), 140.02 (Cph), 149.16 (Cph), 157.15 (C-6), 165.51 (CO ester), 175.05 (C-2); MS: 492 ( $\mathrm{M}^{+}$); Anal. calcd. For $\mathrm{C}_{26} \mathrm{H}_{24} \mathrm{~N}_{2} \mathrm{O}_{4} \mathrm{~S}_{2}$ (\%): C 63.39, H 4.91, N 5.69, S 13.02 Found: C 63.62, H 4.88, N 5.59, S 12.93.

\section{Conclusions}

As-received ZSM-5 was chemically treated in sodium hydroxide at different time intervals and then characterized.

The catalytic activity of the un-treated and alkali-treated catalysts was investigated under Biginelli reaction. Dissolution of siliceous species from the relatively weak parts of the zeolite framework occurred, resulting in the creation of a mesoporous hierarchical structure with good zeolite crystallites on the alkali-treated zeolite. The acidity was slightly changed, with a considerable value of adsorption sites. The superior catalytic activity and high yield of the desired products in a small reaction period was mainly due to the improvement in the adsorptive-diffusive character of ZSM-5 by treatment in alkaline medium and the mechanochemical effect introduced by the ball mill technique.

Supplementary Materials: The following are available online at www.mdpi.com/2073-4344/7/3/84/s1, Figure S1: ${ }^{1} \mathrm{H}$ NMR of compound 4a, Figure S2: ${ }^{13} \mathrm{C}$ NMR of compound 4a, Figure S3: ${ }^{1} \mathrm{H}$ NMR of Compound $4 \mathbf{b}$, Figure S4: ${ }^{13} \mathrm{C}$ NMR of compound 4b, Figure S5: ${ }^{1} \mathrm{H}$ NMR of Compound 4e, Figure S6: ${ }^{13} \mathrm{C}$ NMR of compound 4e, Figure S7: ${ }^{19} \mathrm{~F}$ NMR of Compound 4e, Figure S8: ${ }^{1} \mathrm{H}$ NMR of compound 4f, Figure S9: ${ }^{13} \mathrm{C}$ NMR of compound 4f, Figure S10: ${ }^{1} \mathrm{H}$ NMR of compound 4 h, Figure S11: ${ }^{13} \mathrm{C}$ NMR of compound 4 h, Figure S12: ${ }^{1} \mathrm{H}$ NMR of compound $4 \mathbf{j}$, Figure S13: ${ }^{13} \mathrm{C}$ NMR of compound $4 \mathbf{j}$, Figure S14: ${ }^{1} \mathrm{H}$ NMR of compound 41, Figure S15: ${ }^{13} \mathrm{C}$ NMR of compound 41 . 
Acknowledgments: This research work was funded by the Deanship of Scientific Research (DSR), King Abdulaziz University, Jeddah, under grant number (D-002-432). The authors acknowledge with thanks the DSR's financial support.

Author Contributions: Ameen Shahid, Nesreen S. Ahmed and Tamer S. Saleh conceived and designed the experiments; Ameen Shahid, Nesreen S. Ahmed and Tamer S. Saleh performed the experiments; Tamer S. Saleh and Shaeel Ahmed Al-Thabaiti analyzed the data; Sulaiman N. Basahel and Wilhelm Schwieger contributed reagents/materials/analysis tools; Tamer S. Saleh and Mohamed Mokhtar wrote the paper, share in data analysis and revised the manuscript; Tamer S. Saleh, Wilhelm Schwieger and Mohamed Mokhtar proofread the manuscript.

Conflicts of Interest: The authors declare no conflict of interest.

\section{References}

1. Trost, B.M. The atom economy-A search for synthetic efficiency. Science 1991, 254, 1471-1477. [CrossRef] [PubMed]

2. Sheldon, R.A. The E factor: Fifteen years on. Green Chem. 2007, 9, 1273-1283. [CrossRef]

3. Kappe, C.O. Recent advances in the Biginelli dihydropyrimidine synthesis. New tricks from an old dog. Acc. Chem. Res. 2000, 33, 879-888. [CrossRef] [PubMed]

4. Kappe, C.O. The Biginelli reaction: Development and applications. Tetrahedron 1993, 49, 6937-7168.

5. Kappe, C.O. Synthesis of octahydroquinazolinone derivatives using silica sulfuric acid as an efficient catalyst. Eur. J. Med. Chem. 2000, 35, 1043-1052. [CrossRef]

6. Rovnyak, G.C.; Kimball, S.D.; Beyer, B.; Cucinotta, G.; DiMarco, J.D.; Gougoutas, J.; Hedberg, A.; Malley, M.; McCarthy, J.P.; Zhang, R. Calcium entry blockers and activators: Conformational and structural determinants of dihydropyrimidine calcium channel modulators. J. Med. Chem. 1995, 38, 119-129. [CrossRef] [PubMed]

7. Atwal, K.S.; Swanson, B.N.; Unger, S.E.; Floyd, D.M.; Moreland, S.; Hedberg, A.; O'Reilly, B.C. Dihydropyrimidine calcium channel blockers. 3. 3-Carbamoyl-4-aryl-1,2,3,4-tetrahydro-6-methyl-5pyrimidinecarboxylic acid esters as orally effective antihypertensive agents. J. Med. Chem. 1991, 34, 806-811. [CrossRef] [PubMed]

8. Grover, G.J.; Dzwomczyk, S.; McMullen, D.M.; Normandin, D.E.; Parham, C.S.; Sleph, P.G.; Moreland, S. Pharmacologic profile of the dihydropyrimidine calcium channel blockers SQ 32,547 and SQ 32,946. J. Cardiovasc. Pharmacol. 1995, 26, 289-294. [CrossRef] [PubMed]

9. Kappe, C.O.; Fabian, W.M.F.; Semones, M.A. Conformational analysis of 4-aryl-dihydropyrimidine calcium channel modulators. A comparison of ab initio, semiempirical and X-ray crystallographic studies. Tetrahedron 1997, 53, 2803-2816. [CrossRef]

10. Atwal, K.S.; Rovnyak, G.C.; Kimball, S.D.; Floyd, D.M.; Moreland, S.; Swanson, B.N.; Gougoutas, J.Z.; Schwartz, J.; Smillie, K.M.; Malley, M.F. Dihydropyrimidine calcium channel blockers. II. 3-Substituted-4aryl-1,4-dihydro-6-methyl-5-pyrimidinecarboxylic acid esters as potent mimics of dihydropyridines. J. Med. Chem. 1990, 33, 2629-2635. [CrossRef] [PubMed]

11. Atwal, K.S.; Rovnyak, G.C.; O’Reilly, B.C.; Schwartz, J. Substituted 1,4-dihydropyrimidines. 3. Synthesis of selectively functionalized 2-hetero-1,4-dihydropyrimidines. J. Org. Chem. 1989, 54, 5898-5907. [CrossRef]

12. El-Gaby, M.S.; Ali, G.A.E.H.; El-Maghraby, A.A.; El-Rahman, M.T.A.; Helal, M.H. Synthesis, characterization and in vitro antimicrobial activity of novel 2-thioxo-4-thiazolidinones and 4,4'-bis(2-thioxo-4thiazolidinone-3-yl)diphenylsulfones. Eur. J. Med. Chem. 2009, 44, 4148-4152. [CrossRef] [PubMed]

13. Wolf, R.; Matz, H.; Orion, E.; Tuzun, B.; Tuzun, Y. Dapsone: Unapproved uses or indications. Clin. Dermatol. 2000, 18, 37-53. [CrossRef]

14. GFaget, H.; Pogge, R.C.; Johansen, F.A.; Dinan, J.F.; Prejean, B.M.; Eccles, C.G. The promin treatment of leprosy. A progress report. Int. J. Lepr. Other Mycobact. Dis. 1966, 34, 298-310.

15. Barbuceanu, S.F.; Saramet, I.; Almajan, G.L.; Draghici, C.; Barbuceanu, F.; Bancescu, G. New heterocyclic compounds from 1,2,4-triazole and 1,3,4-thiadiazole class bearing diphenylsulfone moieties. Synthesis, characterization and antimicrobial activity evaluation. Eur. J. Med. Chem. 2012, 49, 417-423. [CrossRef] [PubMed]

16. Barbuceanu, S.F.; Almajan, G.L.; Saramet, I.; Draghici, C.; Socoteanu, R.; Barbuceanu, F.; Bancescu, G. New $S$-alkylated 1,2,4-triazoles incorporating diphenyl sulfone moieties with potential antibacterial activity. J. Serbian Chem. Soc. 2009, 74, 1041-1049. [CrossRef] 
17. Barbuceanu, S.F.; Almajan, G.L.; Saramet, I.; Draghici, C.; Tarcomnicu, A.I.; Bancescu, G. Synthesis, characterization and evaluation of antibacterial activity of some thiazolo[3,2- $b][1,2,4]$ triazole incorporating diphenylsulfone moieties. Eur. J. Med. Chem. 2009, 44, 4752-4757. [CrossRef] [PubMed]

18. Almajan, G.L.; Barbuceanu, S.F.; Almajan, E.R.; Draghici, C.; Saramet, I. Synthesis, characterization and antibacterial activity of some triazole Mannich bases carrying diphenylsulfone moieties. Eur. J. Med. Chem. 2009, 44, 3083-3089. [CrossRef] [PubMed]

19. Almajan, G.L.; Barbuceanu, S.F.; Innocenti, A.; Scozzafava, A.; Supuran, C.T. Carbonic anhydrase inhibitors. Inhibition of the cytosolic and tumor-associated carbonic anhydrase isozymes I, II and IX with some 1,3,4-oxadiazole- and 1,2,4-triazole-thiols. J. Enzyme Inhib. Med. Chem. 2008, 23, 101-107. [CrossRef] [PubMed]

20. Brindaban, A.; Jana, J.U. Indium(III) chloride-catalyzed one-pot synthesis of dihydropyrimidinones by a three-component coupling of 1,3-dicarbonyl compounds, aldehydes, and urea: An improved procedure for the Biginelli reaction. J. Org. Chem. 2000, 65, 6270-6272.

21. Lu, J.; Bai, Y.; Wang, Z.; Yang, B.; Ma, H. One-pot synthesis of 3,4-dihydropyrimidin-2(1H)-ones using lanthanum chloride as a catalyst. Tetrahedron Lett. 2000, 41, 9075-9078. [CrossRef]

22. Hu, E.H.; Sidler, D.R.; Dolling, U.H. Unprecedented catalytic three component one-pot condensation reaction: An efficient synthesis of 5-alkoxycarbonyl-4-aryl-3,4-dihydropyrimidin-2(1H)-ones. J. Org. Chem. 1998, 63, 3454-3457. [CrossRef]

23. Liu, C.; Wang, J.; Li, Y. One-pot synthesis of 3,4-dihydropyrimidin-2(1H)-(thio)ones using strontium(II) nitrate as a catalyst. J. Mol. Catal. A 2006, 258, 367-370. [CrossRef]

24. Yadav, J.S.; Reddy, B.V.S.; Reddy, K.B.; Raj, K.S.; Prasad, A.R. Ultrasound-accelerated synthesis of 3,4-dihydropyrimidin-2(1H)-ones with ceric ammonium nitrate. J. Chem. Soc. Perkin Trans. 2001, 1, 1939-1941. [CrossRef]

25. Al-Mutairi, E.; Narasimharao, K.; Mokhtar, M. Heteropolyacid generated on the surface of iron phosphate nanotubes: Structure and catalytic activity studies. RSC Adv. 2015, 5, 63917-63929. [CrossRef]

26. Maradur, S.P.; Gokavi, G.S. Heteropoly acid catalyzed synthesis of 3,4-dihydropyrimidin-2(1H)-ones. Catal. Commun. 2007, 8, 279-284. [CrossRef]

27. Kozhevnikov, I.V. Catalysis by heteropoly acids and multicomponent polyoxometalates in liquid-phase reactions. Chem. Rev. 1998, 98, 171-198. [CrossRef] [PubMed]

28. Miras, H.N.; Yan, J.; Long, D.L.; Cronin, L. Engineering polyoxometalates with emergent properties. Chem. Soc. Rev. 2012, 41, 7403-7430. [CrossRef] [PubMed]

29. Guo, Y.; Hu, C. Heterogeneous photocatalysis by solid polyoxometalates. J. Mol. Catal. A 2007, 262, $136-148$. [CrossRef]

30. Watson, B.A.; Barteau, M.A.; Haggerty, L.; Lenhoff, A.M.; Weber, R.S. Scanning tunneling microscopy and tunneling spectroscopy of ordered hetero- and isopolyanion arrays on graphite. Langmuir 1992, 8, 1145-1148. [CrossRef]

31. Sun, C.Y.; Liu, S.X.; Liang, D.D.; Shao, K.Z.; Ren, Y.H.; Su, Z.M. Highly stable crystalline catalysts based on a microporous metal-organic framework and polyoxometalates. J. Am. Chem. Soc. 2009, 131, 1883-1888. [CrossRef] [PubMed]

32. Bigi, F.; Carloni, S.; Frullanti, B.; Maggi, R.; Sartori, G. A revision of the Biginelli reaction under solid acid catalysis. Solvent-free synthesis of dihydropyrimidines over montmorillonite KSF. Tetrahedron Lett. 1999, 40, 3465-3468. [CrossRef]

33. Rani, V.R.; Srinivas, N.; Kishan, M.R.; Kulkarni, S.J.; Raghavan, K.V. Zeolite-catalyzed cyclocondensation reaction for the selective synthesis of 3,4-dihydropyrimidin-2(1H)-ones. Green Chem. 2001, 3, 305-306. [CrossRef]

34. Tajbakhsh, M.; Mohajerani, B.; Heravi, M.M.; Ahmadi, A.N. Natural HEU type zeolite catalyzed Biginelli reaction for the synthesis of 3,4-dihydropyrimidin-2(1H) one derivatives. J. Mol. Catal. A 2005, 235, 216-219. [CrossRef]

35. Zendehdel, M.; Mohbinikhaledi, A.; Asgari, A. Zeolite an efficient catalyst for the Biginelli condensation reaction. J. Incl. Phenom. Macrocycl. Chem. 2008, 60, 353-357. [CrossRef]

36. Ogura, M.; Shinomiya, S.Y.; Tateno, J.; Nara, Y.; Nomura, M.; Kikuchi, E.; Matsukata, M. Alkali-treatment technique-new method for modification of structural and acid-catalytic properties of ZSM-5 zeolites. Appl. Catal. A 2001, 219, 33-43. [CrossRef] 
37. Groen, J.C.; Zhu, W.; Brouwer, S.; Huynink, S.J.; Kapteijn, F.; Moulijn, J.A.; Pérez-Ramírez, J. Direct demonstration of enhanced diffusion in mesoporous ZSM-5 zeolite obtained via controlled desilication. J. Am. Chem. Soc. 2007, 129, 355-360. [CrossRef] [PubMed]

38. Meunier, F.C.; Verboekend, D.; Gilson, J.P.; Groen, J.C.; Pérez-Ramírez, J. Influence of crystal size and probe molecule on diffusion in hierarchical ZSM-5 zeolites prepared by desilication. Microporous Mesoporous Mater. 2012, 148, 115-121. [CrossRef]

39. Christensen, C.H.; Johannsen, K.; Törnqvist, E.; Schmidt, I.; Topsøe, H.; Christensen, C.H. Mesoporous zeolite single crystal catalysts: Diffusion and catalysis in hierarchical zeolites. Catal. Today 2007, 128, 117-122. [CrossRef]

40. Tanaka, K. Solvent-free Organic Synthesis, 2nd ed.; Wiley-VCH: Weinheim, Germany, 2008.

41. Kaupp, G. Waste-free synthesis and production all across chemistry with the benefit of self-assembled crystal packings. J. Phys. Org. Chem. 2008, 21, 630-643. [CrossRef]

42. Sahoo, P.K.; Bose, A.; Mal, P. Solvent-free ball-milling Biginelli reaction by subcomopnent synthesis. Eur. J. Org. Chem. 2015, 2015, 6994-6998. [CrossRef]

43. Fernandez, C.; Stan, I.; Gilson, J.P.; Thomas, K.; Vicente, A.; Bonila, A.; Pérez-Ramírez, J. Hierarchical ZSM-5 zeolites in shape-selective xylene isomerization: Role of mesoporosity and acid site speciation. Chem. Eur. J. 2010, 16, 6224-6233. [CrossRef] [PubMed]

44. Van Donk, S.; Janssen, A.H.; Bitter, J.H.; de Jong, K.P. Generation, characterization, and impact of mesopores in zeolite catalysts. Catal. Rev. 2003, 45, 297-319. [CrossRef]

45. Cizmek, A.; Subotic, B.; Aiello, R.; Crea, F.; Nastro, A.; Tuoto, C. Dissolution of high-silica zeolites in alkaline solutions I. Dissolution of silicalite-1 and ZSM-5 with different aluminum content. Microporous Mater. 1995, 4, 159-168. [CrossRef]

46. JAhn, H.; Kolvenbach, R.; Neudeck, C.; Al-Khattaf, S.S.; Jentys, A.; Lercher, J.A. Tailoring mesoscopically structured H-ZSM5 zeolites for toluene methylation. J. Catal. 2014, 311, 271-280.

47. Wang, R.; Liu, Z.-Q. Solvent-free and catalyst-free Biginelli reaction to synthesize ferrocenoyl dihydropyrimidine and kinetic method to express radical-scavenging ability. Org. Chem. 2012, 77, 3952-3958. [CrossRef] [PubMed]

48. Oliverio, M.; Costanzo, P.; Nardi, M.; Rivalta, I.; Procopio, A. Facile ecofriendly synthesis of monastrol and its structural isomers via Biginelli reaction. ACS Sustain. Chem. Eng. 2014, 2, 1228-1233. [CrossRef]

49. Mokhtar, M.; Saleh, T.S.; Ahmed, N.S.; Al-Thabaiti, S.A.; Al-Shareef, R.A. An eco-friendly N-sulfonylation of amines using stable and reusable $\mathrm{Zn}-\mathrm{Al}$-hydrotalcite solid base catalyst under ultrasound irradiation. Ultrason. Sonochem. 2011, 18, 172-176. [CrossRef] [PubMed]

50. Saleh, T.S.; Narasimharao, K.; Ahmed, N.S.; Basahel, S.N.; Al-Thabaiti, S.A.; Mokhtar, M. Mg-Al hydrotalcite as an efficient catalyst for microwave assisted regioselective 1,3-dipolar cycloaddition of nitrilimines with the enaminone derivatives: A green protocol. J. Mol. Catal. A 2013, 367, 12-22. [CrossRef]

51. Suresh, J.S.; Sandhu, J.S. Past, present and future of the Biginelli reaction: A critical perspective. ARKIVOC Online J. Org. Chem. 2012. [CrossRef]

52. McNaught, A.D.; Wilkinson, A. (Eds.) IUPAC Compendium of Chemical Technology (the "Gold Book"), 2nd ed.; Blackwell Scientific Publications: Oxford, UK, 1997.

53. Kaupp, G. Mechanochemistry: The varied applications of mechanical bond-breaking. CrystEngComm 2009, 11, 388-403. [CrossRef]

54. Ulman, A.; Urankar, E. A novel synthesis of 4-[alkyl(aryl)sulfonyl]benzaldehydes: Alkyl(aryl)sulfinate anion as a nucleophile in aromatic substitutions. J. Org. Chem. 1989, 54, 4691-4692. [CrossRef]

55. Yang, H.; Li, Y.; Jiang, M.; Wang, J.; Fu, H. General copper-catalyzed transformations of functional groups from arylboronic acids in water. Chem. Eur. J. 2011, 17, 5652-5660. [CrossRef] [PubMed]

(C) 2017 by the authors. Licensee MDPI, Basel, Switzerland. This article is an open access article distributed under the terms and conditions of the Creative Commons Attribution (CC BY) license (http:/ / creativecommons.org/licenses/by/4.0/). 